\title{
Motivation and Entrepreneurial Cognition
}

As discussed in Chap. 2, opportunity identification is one of the most essential skills of successful entrepreneurs (Ardichvili et al. 2003; Grégoire et al. 2010) and has thus gained considerable importance in the entrepreneurship literature. In addition to prior knowledge, researchers have identified motivation - the behavior-triggering force, which directs behavior and increases persistence with a course of action (Bartol and Martin 1998) - as an important antecedent of opportunity identification. How can opportunity recognition be stimulated by financial rewards? What is the motivational role of values and emotions in the entrepreneurial process? What motivations trigger entrepreneurs' identification and pursuit of opportunities related to sustaining nature and society? Finally, in what follows, we also address questions regarding the potential positive and negative outcomes of entrepreneurial motivation.

\section{Motivation ANd Opportunity IDENTIFICATION}

Scholars studying creativity (e.g., Amabile 1993) and a select group of scholars studying entrepreneurship (e.g., Birley and Westhead 1994; Cardon et al. 2009; Douglas and Shepherd 2002) have concluded that individuals can be driven to entrepreneurship by non-financial/intrinsic motivators. However, most work from the economics and entrepreneurship literature contends that financial reward is the primary driver behind individuals' entrepreneurial engagement (Baumol 1990; Kuratko et al. 1997; 
Langan-Fox and Roth 1995). As an example, studying entrepreneurs in the Midwest, Kuratko et al. (1997: 31) discovered that "extrinsic goals concentrating on wealth" play an important role in individuals' decision to continue in entrepreneurship. Similarly, Baumol (1990: 894) argued that "how the entrepreneur acts at a given time and place depends heavily on ... the reward structure in the economy ... (or) the prevailing rules of the game that govern the payoff." Further, Campbell (1992) developed an economic theory of entrepreneurship, arguing that people choose to engage in entrepreneurship if the anticipated current profit value from entrepreneurial action is greater than the profit value of salaried employment. Finally, Schumpeter (1961) proposed that empire building with the goal of gaining financial reward is a significant motivator for many entrepreneurs.

To more fully understand how financial reward could initiate entrepreneurial action, we draw on motivation theorists Campbell and Pritchard (1976). These authors suggested that motivation is the choice of whether to begin putting forth effort on a particular task as well as the decision of how much effort to put forth and for how long. The first two parts of this motivational decision-namely, deciding to initiate action and determining how much effort to invest-are most important when high effort levels lead to valued end results, including high salary (Kanfer 1990; Vroom 1964).

\section{FinanCIAL ReWARD}

Motivation can be triggered or improved when potential financial rewards are a likely outcome. Scholars have revealed a positive association between financial income and success at particular tasks. Abbey and Dickson (1983), for example, showed that reward levels and achievement motivation are positively associated with the amount of innovations people initiate. Further, Paolillo and Brown (1978) demonstrated a positive association between innovation levels and rewards in a study of employees' ratings of the overall innovative output of their research and development (R\&D) laboratory. Additionally, research on the connection between creativity and the chance to gain financial reward has suggested a positive link between the two (e.g., Woodman et al. 1993), and most creativity scholars argue that there is a strong relationship between creativity and innovativeness (Cummings and O'Connell 1978). Taken together, this research shows that the promise of financial income can increase not only people's ability to generate more opportunities but also those opportunities' level of innovativeness. Indeed, my (Dean) colleague and I (Shepherd and DeTienne 2005) demonstrated 
in an experiment that higher potential financial income levels lead people to identify more potential opportunities. The positive relationship found between financial reward and the amount of opportunities recognized is in line with Gilad and Levine's (1986: 46) argument that "the existence of attractive, potentially profitable business opportunities will attract and 'pull' alert individuals into entrepreneurial activities." Several researchers have explored the role the promise of financial rewards plays in pulling individuals into entrepreneurship (e.g., Katz 1994; Shapiro and Sokol 1982; Gilad and Levine 1986).

Shapiro and Sokol (1982) as well as other scholars (e.g., Douglas and Shepherd 2000; Schjoedt and Shaver 2007) contended that the degree to which individuals are attracted to an entrepreneurial career hinges on both pulls and pushes. In this context, "pushes" are negative characteristics of a person's present situation that encourage him or her to pursue entrepreneurship, including a fixed salary, a reward that does not correspond to the effort expended, and negative displacements. Thus, not only do potentially high financial rewards pull individuals into an entrepreneurial career, the lack of adequate financial reward in a person's present situation could push him or her into this career. In most studies about pushes, entrepreneurship represents self-employment. The motivation logic underlying this careerbased argument for entry into self-employment is also likely applicable to individuals' motivation to recognize potential opportunities.

\section{Financial Reward, Prior Knowledge, AND OPPORTUNITY IDENTIFICATION}

Even when a person is motivated to recognize opportunities, he or she is unlikely to actually identify an opportunity without having prior knowledge (see Chap. 2). Amabile (1997: 42) argued that "expertise (factual knowledge and technical proficiency) is the foundation for all creative work." Similarly, work by Fiet (2007) showed that people who use consideration sets in their opportunity-identification process uncover ideas that are more likely to result in new wealth creation. As such, my (Dean) colleagues and I (DeTienne et al. 2008) proposed that the association between financial reward, prior knowledge, and opportunity identification is more intricate than a clear-cut additive association.

Researchers have mainly explored potential prior knowledge and financial income separately; however, a concomitant consideration of the two is likely to shed additional light on opportunity identification. While the 
associations among prior knowledge, financial reward, and opportunity recognition have not been studied in detail, some research has shown that prior knowledge impacts the association between potential financial reward and individuals' task performance. In his work with exceptionally skilled individuals, for instance, Csikszentmihalyi $(1975,2000)$ found that participants with higher levels of prior knowledge gave undivided attention to a specific task at hand, which at least temporarily protected against other demands that were competing for their attention. The participants felt that they had control over the activity and that their attention was strongly task-focused. Moreover, Maheswaran and Sternthal (1990) revealed that experts (i.e., individuals with high knowledge in a particular domain) are more likely to process messages in a detailed manner in case they are provided with only content information, whereas those who are new to a task more likely process messages when provided with information related to rewards. Thus, it appears that prior knowledge can contribute some motivation in the context of a specific task regardless of whether there is financial reward associated with it.

Take, for example, George de Mestral a Swiss engineer who invented Velcro and his eight-year obsession to replicate the burr-clasping system after examining a cocklebur under a microscope. Ignoring warnings from friends and colleagues that this obsession would lead to financial devastation and personal despair, he left to work in a little mountain hut. $\mathrm{He}$ emerged from the hut after a long period with the underlying technology for Velcro. It took him 14 years after his initial idea to develop a commercializable product. This example clearly demonstrates how a person can be driven by the motivation to solve a problem related to one's prior knowledge instead of by financial reward. Fortunately for de Mestral, he did receive a financial reward in the end.

Applied to opportunity identification, developing a deeper understanding of potential financial reward's motivating effect on opportunity identification likely requires researchers to also consider prior knowledge. With the motivation literature as a basis, we argue that when promised financial reward, people are likely to recognize more opportunities. In addition, these opportunities are more likely to be innovative. Yet, the literature also suggests that knowledge can be a motivator and can thus lessen the positive association between financial reward and both results of opportunity recognition (i.e., number and innovativeness of potential opportunities). More specifically, prior knowledge enables individuals to "see" important linkages between ideas more quickly (Busenitz and Barney 1997; Logan 1990), thus improving their ability to recognize a larger number of opportunities. 
In addition, prior knowledge provides individuals with higher creativity levels to develop opportunities that are more innovative (Cohen and Levinthal 1990; Johnson et al. 1991). Indeed, my (Dean) colleague and I (Shepherd and DeTienne 2005) showed that prior knowledge moderates the association between potential financial reward and the recognition of opportunities. Our study found that high financial reward can at least partially offset the influence of lower knowledge about customer problems on the amount of potential opportunities individuals identify and how innovative those opportunities are.

\section{Entrepreneurial Passion}

Researchers established long ago that passion is a strong motivator of action (see David Hume 1711-1778; Jean Jacques Rosseau 1712-1778) as well as of entrepreneurial decisions (Smilor 1997). We turn to selfdetermination theory (Deci and Ryan 2001; Gagne and Deci 2005; Ryan and Deci 2000) and its extension to passion (Vallerand et al. 2003) to gain a deeper understanding of entrepreneurial motivation. Self-determination theory proposes that individuals attempt to satisfy three basic psychological needs-need for competence, need for relatedness, and need for autonomy - and thus carefully bear these needs in mind when making decisions. When individuals are put in a decision-making situation, the intentionality of their efforts to meet these needs is either controlled or autonomous (Gagne and Deci 2005). Controlled motivation concerns a pressure to act, whereas autonomous motivation refers to individuals' voluntary participation in an activity because they find it enjoyable and interesting. This difference between autonomous and controlled intentionality is reflected in the different types of passion. As a whole, passion is a "strong inclination toward an activity that one loves and finds important, that is, self-defining and in which significant time and energy are invested" (Houlfort et al. 2015: 85). Then, depending on whether passion stems from a controlled or autonomous source, it is labeled as obsessive passion or harmonious passion (Vallerand and Houlfort 2003; Vallerand et al. 2003), respectively.

\section{Fear Motivating Entrepreneurial (In)Action}

Pursuing a potential opportunity can be highly rewarding for the individuals involved in terms of generating financial rewards (Carter 2011), positive emotions (Baron 2008; Cardon et al. 2012), and a higher status/ reputation (Parker and Van Praag 2010). However, since pursuing 
a potential opportunity is full of uncertainty (Knight 1921; McMullen and Shepherd 2006), numerous entrepreneurial undertakings fail (Burgelman and Valikangas 2005; McGrath 1999), which can result in negative financial (Lee et al. 2007, 2011), emotional (Shepherd 2003; Shepherd et al. 2011), and social (Efrat 2005; Semadeni et al. 2008; Shepherd and Patzelt 2015) consequences for those involved (for a summary, see Ucbasaran et al. 2013). Even with the pervasiveness of failure in entrepreneurship, McGrath (1999) contended that entrepreneurs and individuals who would have otherwise become entrepreneurs generally have an anti-failure bias.

While some research has indicated that an anti-failure bias is manifest in a fear of failure and that a fear of failure usually leads to inaction (Alon and Lerner 2008; Wagner and Stenberg; for a review, see Cacciotti and Hayton 2015), some individuals appear to be able to overcome their fears and go after potential opportunities. ${ }^{1}$ These actions are vital in creating wealth for individuals, organizations, and national economies (McGrath 1999; McMullen and Shepherd 2006; Sarasvathy 2001).

According to Conroy (Conroy 2001, 2004; Conroy et al. 2002), fear of failure can be divided into five categories: fear of feeling shame and embarrassment, fear of devaluing one's self-estimate, fear of having an uncertain future, fear of losing social influence, and fear of upsetting important others.

First, the fear of feeling shame and embarrassment refers to individuals' concern that a real personal flaw will be uncovered to the self and to others through a failure event (adapted from Sabini et al. 2001). Quotes from research on entrepreneurs who went through business failure illustrate this shame and embarrassment: "You kind of have ... an embarrassing grief about it that, you know, it's not a very nice feeling really. And you have a lot of regret and a lot of guilt" (Byrne and Shepherd 2015: 380). Anticipating these types of feelings over a failure can lead to fear that influences how a person assesses the financial costs of failure in the entrepreneurial decision-making process. More specifically, when entrepreneurs have greater fear of feeling shame and embarrassment, they likely weigh financial costs more when deciding whether to exploit an entrepreneurial opportunity or not. Financial losses are often noticed by stakeholders and frequently become known by others in the community. Thus, for entrepreneurs who believe it is embarrassing to fail in front of others, negative performance feedback - which is rather easy to communicate publiclymay generate feelings of embarrassment (Ashford 1986; Smith and McElwee 2011). Anticipating this shame and embarrassment may cause 
individuals to protect themselves from exposure to such financial risks as they believe they have simply too much at stake.

Second, fear of devaluing one's self-estimate refers to unease about a drop in others' appraisal of one's capabilities in relation to a group whose performance is known (adapted from Gilinsky 1949). Indeed, failure can make individuals begin to doubt their knowledge and ability to successfully undertake certain tasks (Gatewood et al. 2002; Hoang and Gimeno 2010) as well as make them question their self-worth (Jenkins et al. 2014; Laguna 2013), have lower self-esteem (Shepherd and Cardon 2009), and start to doubt the control they have over important aspects of their lives (Folkman and Moskowitz 2004; Stanton et al. 2002). In turn, entrepreneurs are likely to weigh financial costs more when they fear that failure will negatively affect their self-estimation about their own capabilities and talent. Financial performance is either the objective of pursuing an entrepreneurial opportunity or the channel for accomplishing an even greater goal (Miller et al. 2012). As such, closing a business because of financial losses is a very clear indication that the entrepreneur has failed in his or her primary aim, and it seems that the more the failure costs financially, the larger the "potential hit" to the entrepreneur's self-estimate will be-a position those who fear the devaluation of their self-estimate would not want to be in.

Third, a fear of having an uncertain future entails individuals' fear about not knowing where their life is heading. This fear is illustrated in work by my (Dean) colleague and me (Byrne and Shepherd 2015: 384), in which we described the situation of an entrepreneur whose business failed and his frustrations over not fully knowing what was going to unfold next: "'Suddenly you get this bit of paper from the [officials] telling you, you can't be a company director. So that, the whole vagueness and uncertainty over that bit is, ahhh.' He does not finish this sentence, he just makes an annoyed sound and shakes his head." Similar to the above, entrepreneurs who feel uneasy about such uncertainty are likely to weigh financial costs more when deciding whether to pursue an opportunity or not. A failure that costs less financially will have a lower impact on the entrepreneur's slack resources than a costlier failure. The greater the financial slack (even if it is still low), the bigger the cushion for tough times (Carroll et al. 1992; Fafchamps and Lund 2003), the greater the ability to develop future options and plans (Lentz and Tranaes 2005; Wanberg et al. 1999), and thus the more certainty about the future. Nevertheless, higher losses from a failure could make future plans unaffordable or inaccessible. That is, a substantial financially damaging failure (to the extent the 
entrepreneur views it as traumatic) can destroy one's central beliefs about the self, others, and life in general, making everything appear less predictable (Janoff-Bulman 1985; Haynie and Shepherd 2011). Therefore, entrepreneurs who are afraid of changing plans and uncertainty may pay a great deal of attention to potential financial costs when making decisions about opportunities.

Fourth, fear of losing social influence denotes people's worry that they will be less able to use their opinions and attitudes to influence others' opinions and attitudes (adapted from Martin and Hewstone 2003). The higher a failure's financial costs, the higher the probability that others will notice the failure, often resulting in stigma for the individuals involved (Cardon et al. 2011; Semadeni et al. 2008; Sutton and Callahan 1987). For instance, our research (Shepherd and Patzelt 2015) showed that individuals with substantial financial losses as a result of failure are stigmatized more than those with lower losses. Stigma is a form of social stain as the individual being stigmatized experiences defamation that harms his or her reputation (see Cardon et al. 2011; Shepherd and Patzelt 2015). Ultimately, the social influence of stigmatized individuals diminishes significantly. Sutton and Callahan (1987), for instance, reported that managers of a firm that entered Chapter 11 bankruptcy found that former associates ceased contact with them due to the failure (Sutton and Callahan 1987). Unsurprisingly, individuals who are afraid of losing social influence will likely be significantly affected by the financial costs associated with failure when making entrepreneurial decisions.

Finally, fear of upsetting important others refers to an individual's fear of disapproval from people critical to his or her well-being. For individuals who have this fear, large financial costs are often especially worrisome because a costly failure is likely to upset important others. For instance, the financial costs of failure not only affect the entrepreneur but can also negatively impact the firm's stakeholders and even the entrepreneur's family. Indeed, stakeholders are generally people who are important to the entrepreneur and his or her venture (Mitchell et al. 1997; Seldon and Fletcher 2015; Vandekerckhove and Dentchev 2005), friends and family often make equity investments in the business (Kotha and George 2012), and entrepreneurs frequently develop close relationships with their employees (Breugst et al. 2012). Thus, financially costly failures are likely to upset investors who could potentially lose more money (Amit et al. 1990; Mason and Harrison 2002), employees who could lose their jobs (or have to end relationships with people who are let go) (Fineman 1999; Jordan et al. 2002), and other 
stakeholders who could potentially lose their reputation and/or social standing (Sutton and Callahan 1987). For instance, referencing an entrepreneur whose venture failed, the Scottish Star newspaper (April 23, 2011) reported that "Chief executive Sam said he 'had been left with no alternative' but to pull the plug. He added: 'Making all the employees redundant is genuinely heart breaking'" (cited in Byrne and Shepherd 2015: 382). As with the other four types of fear, the more afraid an entrepreneur is of letting important stakeholders down, the more he or she is likely to emphasize the financial costs of failure when making entrepreneurial decisions.

If the Japanese proverb's argument that "fear is only as deep as the mind allows" is true, then individuals may be motivated enough to overcome their fears when making entrepreneurial decisions. Thus, a key question arises: why can some individuals overcome their fear of failure and choose to act on potential opportunities whereas others succumb to their fear and do not?

As mentioned earlier, individuals who have high obsessive passion for an activity are more likely to choose to adamantly continue their pursuit of the beloved activity (Curran et al. 2015; Houlfort et al. 2015) and to remain engaged in the activity even when presented with information suggesting the imprudence of this course of action (Stephan et al. 2009). In the context of entrepreneurship, such behavior includes disregarding (or putting minimal emphasis on) information about the high financial costs associated with failure when choosing whether to pursue potential opportunities.

\section{Fears, Passion, and Entrepreneurial Action}

One particular point of interest to theorizing about fear of failure is that obsessive passion seems to affect the way individuals make decisions under threat and can lead to maladaptive outcomes (Curran et al. 2015; Donahue et al. 2009; Hodgins and Knee 2002; Vallerand et al. 2008, 2010). Because people who "cannot help but engage in their professional activities" (Houlfort et al. 2015: 85) tend to have obsessive passion, they continue with a particular response even when they encounter signals suggesting that the response is unsuitable (i.e., they have a rigid response), which can ultimately result in negative outcomes. For example, obsessively passionate workers will continue with projects irrespective of information indicating that persisting unchanged will cause undesirable consequences (Stephan et al. 2009). They feel obligated to take on tasks for reasons besides the tasks' outcomes, so their engagement in such tasks is compulsive and rigid (Curran et al. 2015). 
Additionally, obsessive passion has been linked to risky behaviors (Rip et al. 2006). Researchers have found, for instance, that obsessively passionate athletes' rigid persistence can lead to risky training, thereby increasing their vulnerability to injury (Stephan et al. 2009; Vallerand et al. 2003), and the rigid persistence of individuals who have high obsessive passion for the Internet and for soccer (Vallerand et al. 2008) is associated with poor relationship quality. Overall, obsessive passion is linked to a variety of negative outcomes at the individual level, including conflict with other life spheres (Vallerand et al. 2010), aggressive behavior (Donahue et al. 2009), and difficulties in partner relationships (Vallerand et al. 2008). For numerous other activities—such as sports, gaming, and shopping-obsessive passion often leads to unproductive outcomes, thus creating conditions that would make it difficult to continue engagement or to be successful in the long term. Thus, obsessive passion appears to overpower individuals' appraisal of threats (e.g., the threat of injury, relationship loss, etc.) associated with certain activities (i.e., activities the individual is passionate about).

People who are obsessively passionate believe they cannot live without engaging in the activity they are passionate about (Vallerand et al. 2003), and they will give that activity top priority when making decisions regarding the investment of their time and energy. As Vallerand et al. (2003: 757) fittingly remarked, obsessively passionate individuals "cannot help but to engage in the passionate activity. The passion must run its course as it controls the person." On the other hand, individuals who have low obsessive passion about a potential entrepreneurial opportunity are not as dedicated to such activity and are thus more likely to think about how investing in the focal activity will affect other aspects of their lives (Shah et al. 2002). That is, their fear of failure is associated with elements of life domains outside the focal activity. For less obsessively passionate individuals, fear of failure may motivate them to prioritize their life domains and psychological needs such that large financial opportunity costs are likely to lessen the attractiveness of acting upon potential opportunities. However, individuals who are very obsessively passionate are likely to emphasize life domains less and concentrate on the possible upsides of acting on potential opportunities. For such individuals, the entrepreneurial activity at hand is their main focus-it "commands" how they invest their time and energy. Consequently, they are less likely to become preoccupied with fears about the potential undesirable outcomes of their actions. Indeed, my (Dean) colleagues and I (Shepherd et al. 2018) showed that the negative emphasis individuals place 
on the financial costs of failure when making entrepreneurial decisions increases with fear of failure for those with low obsessive passion but less so for those with high obsessive passion.

\section{Entrepreneurial Motivation for Sustaining Nature AND/OR COMMUNities}

Aside from knowledge (see Chap. 2), the motivation to focus attention is a key factor in opportunity recognition (Baron 2006; Kirzner 1979; McMullen and Shepherd 2006). Motivation to direct one's attention to preserving natural and communal environments likely develops when people or organizations sense that their psychological and/or physical health is at risk.

First, people are frequently motivated to take action on sustainable development opportunities that increase or preserve their personal health. For instance, damage to the natural environment from pollution jeopardizes many peoples' lives, and the overuse of natural resources decreases life support by reducing the availability of food (Sala 2006). Furthermore, research has shown that a deteriorating communal environment, including the loss of cultural identity, is associated with alcoholism (Spicer 2001) and diminished expectancy of life (McDermott et al. 1998) among members of disabled ethnic minorities. As such, individuals who face these threats are likely to be highly motivated to direct their attention to and exploit opportunities that improve practices associated with the exploitation of natural resources, diminish pollution, and eliminate oppression of ethnic groups.

In terms of psychological threats, self-determination theory attempts to explain the psychological processes underlying optimal psychological functioning and health (Ryan and Deci 2000). More specifically, the aspects of life that fulfill people's needs for competence, relatedness, and autonomy also improve psychological well-being (Ryan and Deci 2000). When something threatens these aspects of an individual's life, his or her psychological well-being is also threatened, which causes the person to dedicate more attention to the threatening part of the environment. The more attention the individual places on this threat, the more likely he or she will recognize an opportunity associated with that part of the environment.

Additionally, deteriorating natural and communal environments can jeopardize individuals' need for competence, thus motivating them to pay more attention to relevant aspects of the environment. When people begin to believe that nature is on the decline, they may start to feel that they-as 
part of society - are not competently managing the natural environment in a way that ensures suitable living conditions for the generations to come. For example, the negative outcomes of climate change and ozonelayer depletion will become more substantial for the next generations (Dentener et al. 2006), and the extinction of species as well as the decline of certain natural habitats including forests and oceans cannot be fully rectified in the future. In a similar vein, a deteriorating communal environment may hinder individuals from meeting their need for competence due to its impact on the next generation's well-being. As an example, family disruption harms the well-being of children and grandchildren in impacted families (Amato 2005). To the degree that individuals ascribe such negative outcomes to their own or their society's failure to preserve natural and communal environments, their need for competence will be unsatisfied and their sensitivity to opportunities that maintain the environment will increase.

Deteriorating natural and communal environments also negatively affect people's need for relatedness (i.e., their need to connect with others) (Ryan and Deci 2000). First, declining environmental conditions that will primarily harm the subsequent generation are likely to make it more challenging for individuals to develop relationships with people in that generation. For instance, children may blame their parents (or the generation of their grandparents) for leading self-centered and egoistical lives that exploited and damaged nature and for causing problems that the children and their generation will have to endure.

Second, a deteriorating natural environment generally causes unequal suffering among the earth's population; often, the individuals who suffer most did not cause the decline, thus making it challenging for both groups of people to connect. Ozone-layer depletion, global warming, and overfishing, for instance, can largely be attributed to industrial activities and use in developed regions and countries, yet the numerous and often significant costs of these activities in the form of destroyed ecosystems are forced on developing countries (Srinivasan et al. 2008). In turn, individuals from these developing countries may reproach the developed countries for their self-centeredness and irresponsibility, thus harming interpersonal relationship building across different societies.

Third, weakened communal environments can disturb salient social relationships, for example, between parents and their children when families are disrupted. With more struggles and relationship issues, people's need for relatedness is unmet. In this case, they are likely to focus on 
opportunities to preserve natural and communal environments to avoid harm to others in the society and the next generation.

Finally, changes to natural and communal environments could also put individuals' needs for autonomy at risk. In order to experience autonomy, individuals need to have a set of available options (Ryan and Deci 2000). However, with deteriorating environmental conditions, people's options usually decrease. For instance, global warming has killed (or is killing) coral reefs (Tourtellot 2007), and climate change has also hindered the growth of crops and other nutritious plants in many areas, thus limiting the amount and diversity of food available throughout the world. Furthermore, when social groups are disturbed, people's options for developing social ties with other individuals, especially other group members, are decreased. Thus, as these examples illustrate, the more natural and communal environmental changes lessen the options individuals have, the more their need for autonomy will remain unmet, and the more they will be inspired to focus on opportunities that preserve the environment.

People's motivation to act on sustainable opportunities seems to increase as their physical and psychological health becomes progressively threatened. That is, the more threatened people feel, the more they tend to direct their attention toward the causes of that threat, and the less attention they tend to direct toward non-threat-related information (McMullen et al. 2009). Thus, when the threat to natural and communal environments is high, individuals are highly likely to act on opportunities to preserve those environments. The threat individuals sense from declining natural and communal environments likely affects the degree to which they combine their knowledge about entrepreneurship and their environmental knowledge to identify a sustainability opportunity. Generally, after individuals perceive a threat and overcome their initial fear response, they thoughtfully search for opportunities to deal with the threat (Beck and Clark 1997). While "elaborative strategic processing of threat," people process information slowly and a "secondary appraisal process occurs in which anxious individuals evaluate the availability and effectiveness of their coping resources to deal with the perceived threat" (Beck and Clark 1997: 53). In other words, individuals whose psychological and physical health is endangered by environmental (natural or communal) deterioration will seek and assess opportunities to handle that threat and, in doing so, will be driven to utilize their prior environmental/communal knowledge as well as their entrepreneurial knowledge. As an individual undertakes assessment activities to deal with a threat, it becomes increasingly 
likely that he or she will uncover a complementary relationship between his or her environmental and entrepreneurial knowledge such that both forms of knowledge can be joined to help the person identify an opportunity. On the other hand, if the individual senses a lower threat from environmental decline and engages in fewer assessment activities to deal with the threat, while he or she may possess both types of knowledge (i.e., of the natural/communal environment and of entrepreneurship), he or she is unlikely to be motivated to connect the two forms of knowledge to identify an opportunity.

\section{Entrepreneurial Motivation Toward Developing Society}

Individuals and organizations vary in terms of their motivation to focus attention on generating economic and non-economic gains for disadvantaged others. We concentrate on two sources that likely explain some of this variance: the degree to which individuals feel physically and psychologically threatened by the (expected) condition of society and their altruism.

People will be more motivated to exploit opportunities to improve society when they believe that their physical well-being is at risk due to the present or expected state of society. Before 1983, for example, the institutional environment in the United States offered pharmaceutical companies few incentives to create drugs to treat rare diseases because demand for such drugs was low. As a result, many patients with rare diseases had significant difficulty obtaining much-needed medical treatment. This threat to their own health drove some of these patients to act on opportunities to change the institutional environment such that it incentivizes pharmaceutical firms to create drugs for rare diseases. Some of these patients founded the National Organization for Rare Disorders and began the Orphan Drug Act. The Orphan Drug Act is a legal framework providing marketing exclusivity for rare disease drugs to pharmaceutical companies. In turn, these actions considerably improved the medical situation not only for the patients themselves but also for others in society (Austin et al. 2006).

Furthermore, the attention individuals pay to opportunities that develop society will grow with increasing threats to their psychological needs for competence, relatedness, and autonomy (Ryan and Deci 2000). For instance, some countries' legal frameworks are incapable of dealing 
with corruption and violence (Paldam 2002; Karstedt 2006), so people living in these countries may believe that they (and the society they live in) are incapable of developing an institutional setting that provides them and their children peace and safety. In addition, identifying a sustainable development opportunity may enable individuals to handle a threat to their need for relatedness. For example, identifying an opportunity to prompt institutional change and improve minority rights enables individuals to develop relationships with minority groups as well as with philanthropic and volunteer supporters of the cause (Austin et al. 2006). Finally, individuals may focus their attention on entrepreneurial opportunities that develop society to meet their need for autonomy. For example, members of minority and ethnic groups often do not have equal opportunities or rights compared to the majority population in a country, which hinders their (and their children's) ability to improve their socioeconomic status and personal development. Such people are thus likely to be motivated to pursue opportunities that enhance their situation and the options available to them because these types of opportunities can help satisfy their psychological need for autonomy.

A rising threat to individuals' physical or psychological health due to the (anticipated) state of society will affect the association between their knowledge of the natural/communal environment, their entrepreneurial knowledge, and the probability that they will identify a sustainable development opportunity. As explained above, increased physical and psychological threat prompts careful consideration and the identification of opportunities to overcome that threat (Beck and Clark 1997), which in turn likely leads individuals to uncover complementarities between their environmental and entrepreneurial knowledge. For example, an individual with knowledge about both pollution-reduction technologies and auto markets may not identify opportunities to lessen air pollution by introducing new technologies into cars because he or she does not perceive air pollution caused by cars to be an issue for his or her society. However, if that same person lives in a country where many people suffer with serious health problems caused by traffic-induced air pollution, his or her need for competence may go unmet because he or she (and others) is unable to help preserve a healthy society. In turn, this psychological threat is likely to drive the individual to seek opportunities that will create a healthier society, and the individual is more likely to identify an opportunity to develop cars that put out fewer emissions based on complementarities between his or her prior knowledge of air pollution and the auto market. 
Aside from threat, altruism can direct people's attention toward opportunities that develop society. This altruistic motivation to assist others generally occurs when people experience empathy and sympathy for those who are disadvantaged (Batson and Shaw 1991; Davis 1996). People who are high in empathy think and feel themselves into disadvantaged others' lives and experience emotions themselves that are similar to the others' emotions (Eisenberg 2000). Individuals who can empathize with people in very poor societies may personally experience (at least to some extent) those people's grief over providing life support for their children. It follows, then, that the more individuals empathize with the poor, the higher their motivation to pay attention to opportunities that could offset poor individuals' negative emotional experiences and distress since they are partially their own emotions. Such individuals are very likely to be motivated to act on opportunities for sustainable development that can transform poorer individuals' situation-in doing so they can also better their own emotional state. For instance, these types of individuals are likely to notice opportunities that improve poor children's health while also protecting the natural environment, such as developing inexpensive processes to convert polluted water into drinking water (Prahalad 2007).

Like empathetic individuals, sympathetic people can think and feel themselves into disadvantaged others' situations; however, unlike their empathetic counterparts, sympathetic people experience emotions that differ from these others' emotions (Eisenberg 2000). For example, those who sympathize with people who are very poor understand these people's sorrows regarding their children's health and nutrition. However, they will not personally feel this sadness, instead pitying the people for their difficult situation. Pity is an altruistic emotion that drives people to help ease the suffering of others even when giving assistance leads to significant individual costs (Dijker 2001). Overall, people who sympathize with the poor will be driven to help them and be motivated to exploit opportunities that can enhance their life.

How much empathy and sympathy motivate individuals to act on opportunities that develop people and society seems to hinge on the level of personal distress that empathy and sympathy cause them. Personal distress can stem from empathetic or sympathetic overarousal (Hoffman 1982), which occurs in highly negative emotional situations that threaten an individual's psychological well-being (Eisenberg 2000). For instance, people who empathize with those who are poor and worry about their children's nutrition personally experience that worry, which can generate personal distress. 
To avoid this distress, people sometimes become less altruistic. Instead, these people concentrate more on themselves (e.g., Wood et al. 1990), thus decreasing their motivation to act on entrepreneurial opportunities that aid others. In other words, highly distressed empathetic individuals are likely to pay less attention to the poor and their suffering to avoid personally experiencing this negative emotional state. However, those who are better able to regulate their own emotions and handle their own distress will be better able to empathize and sympathize with disadvantaged others without becoming overly distressed (Eisenberg 2000). These people's psychological health is threatened less when they feel empathy and sympathy, thus making them more motivated to help others with their problems and act on potential opportunities to develop society.

Individuals' altruism, empathy, and sympathy are also likely to affect the degree to which entrepreneurial knowledge improves the positive association between prior knowledge about natural/communal environments and the likelihood of identifying sustainable development opportunities. People may have both environmental and entrepreneurial knowledge but may not be motivated to uncover complementarities between the two or combine them to identify opportunities that preserve the environment and develop society. However, altruism, empathy, and sympathy can provide such motivation.

\section{Health and Entrepreneurial Motivation}

Research has shown that people with health-related limitations often freely choose entrepreneurial careers. For instance, people who perceive barriers to advancement in more customary employment roles (e.g., individuals with disabilities) are likely to be attracted to entrepreneurial careers (Kendall et al. 2006; Callahan et al. 2002). More specifically, people with disabilities often prefer entrepreneurial careers because such careers tend to offer better accommodations for disability-related issues (Arnold and Seekins 2002; Hagner and Davies 2002). Although most organizations have made physical-access accommodations for employees in the workplace (Batavia and Schriner 2001), those with disabilities often need additional accommodations, such as flexibility to arrange their schedule around health issues and treatment. These individuals tend to highly value autonomy (Arnold and Seekins 2002; Hagner and Davies 2002). My (Dean) colleague and I (Haynie and Shepherd 2011), for example, found that soldiers and marines who were injured in Iraq and Afghanistan were 
driven to become entrepreneurs partially because they needed autonomy. They needed autonomy because following orders from someone else almost led to their death, and when handling their health problems, they were often forced to follow doctors' and nurses' orders. Similarly, my (Holger) colleagues and I (Wiklund et al. 2016) showed that individuals suffering from ADHD find entrepreneurship to be an attractive career path because it allows for an adjustment of the work environment to ADHD-related symptoms (e.g., varying energy levels, changing attentional foci, problems with routine activities). Indeed, statistics reveal that those who are disabled are more than twice as likely to choose self-employment than people without disabilities (US Census Bureau 2002). Thus, it appears that limitations stemming from health issues motivate such individuals to choose entrepreneurial careers. These careers offer the flexibility that enables them to take care of their health-related needs and obtain treatment.

The findings and gaps associated with this topic offer a variety of research opportunities. First, while entrepreneurial careers typically offer higher flexibility than salaried employment, the amount and type of flexibility provided across entrepreneurial careers varies. For example, venture founders who want to utilize outside capital to develop their business usually find that they must relinquish more responsibility for running the business than individuals who limit business growth to what they can finance using internal capital sources (Wasserman 2008). Along these lines, different health issues may necessitate different work-related flexibility. It is unclear what are the various flexibility needs associated with major health problems that motivate individuals to become entrepreneurs. How do these entrepreneurs take advantage of this flexibility to improve their health or lessen their health problems? Why are some entrepreneurs able to draw on flexibility more effectively to lessen their health problems than other entrepreneurs? The discussion above focused on people who are drawn to an entrepreneurial career's flexibility to deal with health problems; yet, other entrepreneurs (driven by other motives) are also likely to use the flexibility of their career to improve their health. For instance, an entrepreneurial career's flexibility could allow some to engage in recreational or sporting activities.

Second, entrepreneurial ventures are likely to differ in the autonomy they provide, and entrepreneurs are also likely to desire varying autonomy levels. Researchers can in more detail investigate the association between individuals' health problems and their desire for autonomy. For example, they can explore why some health-related problems are associated with the 
desire for more autonomy than other problems. How are these differences embodied in the new firms created? As detailed above, my (Dean) colleague and I (Haynie and Shepherd 2011) offered some preliminary insights about marines and soldiers who were injured in combat and their desire for autonomy; their findings imply that when a person's healthrelated problem is connected to loss of control (lack of control causing health-related problems or health-related problems causing lack of control), he or she is likely to strongly desire the autonomy found in an entrepreneurial career.

Third, in addition to autonomy, flexibility, and physical accommodations, what other factors do individuals with health-related problems consider when choosing the career of an entrepreneur or when choosing between different types and paths of entrepreneurial careers? As mentioned earlier, self-determination theory posits that people must also satisfy their psychological needs for competence and belonging (Ryan and Deci 2000; Deci and Ryan 1985). When poor health stops individuals from undertaking particular tasks, it appears they have an even stronger desire to decide for an entrepreneurial career through which they can develop and use new competencies (Haynie and Shepherd 2011). Thus, when becoming an entrepreneur helps individuals who have lost confidence in their competence (or the capability to display their competence) to regain that confidence, health benefits may follow (especially benefits related to psychological health).

Fourth, poor health may result in loneliness (Molloy et al. 2010). Loneliness is an emotional state that occurs when an individual feels estranged from and/or misunderstood by others and thus feels a lack of social integration (Rook 1984; Donaldson and Watson 1996). (This is different from being alone, which people sometimes seek for pleasure.) Research has shown that loneliness can worsen health-related problems (Hawkley and Cacioppo 2010; Sugisawa et al. 1994; Thurston and Kubzansky 2009). Indeed, one study showed that lonely people have a $45 \%$ higher mortality rate than people who are not lonely (Holt-Lunstad et al. 2010). How does the pursuit of an entrepreneurial career influence healthrelated loneliness? Entrepreneurs are frequently referred to as "lone wolfs," and "being the boss" typically separates the entrepreneur from his or her subordinates. This separation may cause feelings of isolation and loneliness (Akande 1994; Gumpert and Boyd 1984; Hannafey 2003). Yet, entrepreneurs can usually choose with whom they wish to work (Forbes et al. 2006). Additionally, some new firms are created by a founding team 
(Ucbasaran et al. 2003), which enables team members to form friendships that can counteract loneliness.

Fifth, while people suffering health problems may decide to become an entrepreneur for the reasons discussed above, the costs stemming from health problems sometimes make an entrepreneurial career infeasible. Poor health can be financially costly, frequently causing many out-of-pocket expenses, lost earnings, and depleted household assets (Poterba et al. 2010). These costs can diminish one's financial resources for starting a new venture. Yet, in line with the definition of entrepreneurship as the pursuit of opportunities beyond the resources one presently has (Baker and Nelson 2005; Brown et al. 2001; Stevenson 1983) as well as work on effectual reasoning highlighting entrepreneurs' current resources as a starting point (Sarasvathy 2001), entrepreneurship is still viable with limited resources.

Finally, other resources aside from financial resources can be exhausted by health-related problems; poor health can also take time (Stewart et al. 2003; Weiss et al. 2000) and energy away from activities related to work (or perhaps the opposite is true in some situations-viz., an entrepreneurial venture creates energy that transforms the health issue).

\section{Entrepreneurial Motivation and Others’ Health}

As discussed above, people who directly experience health problems are often motivated to recognize and act on opportunities to overcome their poor health. However, individuals do not need to experience health problems directly to be driven to identify and exploit opportunities to help with others' health problems. First, some individuals have prosocial motivation-namely, "the desire to expend effort based on a concern for helping or contributing to other people" (Grant and Berry 201 1: 77). Prosocial motivation influences cognitive processing (Kunda 1990; Nickerson 1998). Grant and Berry (2011) found that prosocial motivation can lead to perspective taking, which enables people to generalize valuable ideas in more creative ways. Perspective taking is "a cognitive process in which individuals adopt others' viewpoints in an attempt to understand their preferences, values, and needs". This process can give individuals insight into the nature of others' health problems, which is essential for them to recognize opportunities that help solve these problems. While prosocial motivation does not necessarily eliminate self-interested actions, to at least some degree, the "rubber meets the road" with how one manages their intellectual property. For example, when reporting why he did 
not patent the Solar Ear (an inexpensive, durable, and solar-powered hearing aid), Howard Weinstein noted that the cost of intellectual property protection would increase the overall product price, which went against his goal of helping as many people as possible with the technology. Further, he stated, "I actually want one of the Big 5 to copy us and use their distribution power to get more low cost hearing aids and batteries to developing countries" (kopernik.info/en-us/story/howard-weinstein-solar-ear). Thus, prosocial motivation not only shapes people's cognitions to offer insight into potentially beneficial health solutions, but it also motivates them to act on these opportunities.

Second, research has shown that prosocial motivation can result in perspective taking and eventually innovations among employees (Grant and Berry 2011). Again, prosocial motivation does not necessarily exclude benefits for the actor, but prosocially motivated individuals have a desire to aid others (Grant 2007; Grant and Berry 2011). Similarly, we (Shepherd and Patzelt 2015) proposed that although health entrepreneurship may create profit for entrepreneurs, it is also highly likely to improve others' health. Researchers have the opportunity to explore phenomena that can "make a difference" (health being the dependent variable) while simultaneously furthering their careers by publishing high-quality research with a deep impact. Thus, we hope scholars are prosocially motivated when choosing their research topics.

Third, entrepreneurs are likely to vary widely in their prosocial motivation (although this remains an empirical question). What influence does such variance in prosocial motivation have on health entrepreneurship? It could be that only highly prosocially motivated people recognize and act on health-related opportunities. However, because of the high possibility of generating profit, it is more likely that "all sorts" of entrepreneurs decide to enter this industry. A more fruitful line of research could be exploring differences in exploited opportunities in relation to entrepreneurs' level of prosocial motivation. For instance, do more prosocially motivated entrepreneurs act on more radical health opportunities compared to those who are less prosocially motivated? If so, is the reason for such action because these entrepreneurs engage in more perspective taking to isolate opportunities that would be more suitable for solving health problems (consistent with Grant and Berry 2011)? Alternatively, is an entrepreneur's willingness to accept uncertainty to act on a more radical opportunity bolstered by his or her prosocial motivation? Perhaps individuals with higher prosocial motivation are more prone to exploiting opportunities that have a higher 
likelihood of greatly reducing others' suffering. In addition, scholars can investigate why some entrepreneurs who are prosocially motivated exploit opportunities that solve others' health problems, whereas other prosocially motivated entrepreneurs are focused on opportunities that aid others in ways unrelated to health issues.

Finally, there can be a dark side to pursuing entrepreneurial opportunities that improve others' health: (1) The process of exploiting opportunities to improve others' health may have adverse health implications for the entrepreneur, which deplete energy (and therefore motivation) from the entrepreneurial effort. (2) Potential health opportunities (as all entrepreneurial opportunities) are inherently uncertain, and their pursuit could result in failure. When failure occurs, it could come with health repercussions that negatively affect subsequent entrepreneurial motivation. Entrepreneurial grief (Shepherd 2003), for instance, is likely greater when a business failure leads to the continuation of others' suffering that was going to be improved through the venture. Further, when entrepreneurs are a key source of health benefits for others, the implications to their own health from their entrepreneurial efforts increase in importance.

\section{Entrepreneurial Motivation and the Destruction of Nature}

As detailed in Chap. 2 (and more briefly above), harm to the natural environment refers to damaging the inherent worth of the physical world (Muehlebach 2001)—namely, the earth, biodiversity, and ecosystems (Parris and Kates 2003) —and reducing a source of resources and services to support present populations and future generations (Daily 1997). There are many reasons why an opportunity's specific harm to the natural environment could adversely affect entrepreneurs' evaluations of its appeal. For instance, entrepreneurs may foresee harm to their personal and/or their venture's reputation as a result of pursuing an opportunity that damages the environment (which is in line with findings related to the relationship between illegal activity and damage to a manager's and an organization's reputation [Karpoff et al. 2008; Karpoff and Lott 1993; Wiesenfeld et al. 2008]). However, entrepreneurs are likely to judge the significance of expected losses differently because personal values are likely to influence such judgments. For example, Agle et al. (1999) showed that other-regarding values affect the importance CEOs ascribe to employees when making decisions that influence corporate performance. Values are "an enduring 
belief that a specific mode of conduct or end-state of existence is personally or socially preferable to an opposite or converse mode of conduct or endstate of existence" (Rokeach 1973: 5). Thus, values are guiding beliefs (Schwartz and Bilsky 1990) for decision making and ensuing action (Fishbein and Ajzen 1972; Spash 2002; Thøgersen and Olander 2002).

In terms of the natural environment, respect for nature refers to "prudence in the management of all living species and natural resources," so they can be "preserved and passed on to our descendants" as well as the realization that "current patterns of production and consumption are unsustainable and must be changed" (United Nations General Assembly 2000). Finding an opportunity that could damage the natural environment to be highly appealing is likely to be contradictory to these overall values. Thus, when provided with information about an opportunity that will negatively affect the natural environment, entrepreneurs with stronger pro-environmental values will focus more attention on that information and will emphasize it more in their opportunity evaluations than entrepreneurs with weaker pro-environmental values. Indeed, we and a colleague (Shepherd et al. 2013) revealed that when entrepreneurs assess opportunities' attractiveness, the stronger their pro-environmental values, the more they emphasize the specific harm to the natural environment resulting from the opportunities in their decision making.

However, having strong pro-environmental values does not guarantee that entrepreneurs will not try to exploit opportunities that damage the natural environment; some entrepreneurs disengage such values during the decision-making process. For instance, people who feel they lack control over their own lives but believe that events and experiences in life are controlled by fate and luck instead of their own initiative (Detert et al. 2008; Levenson 1981) tend to disengage their values more readily. These beliefs in one's capacity to exercise control include both beliefs about one's ability to effectively complete essential tasks and the belief that this performance influences ensuing events and outcomes.

\section{Entrepreneurial Self-Efficacy}

Self-efficacy refers to the personal belief that one can achieve whatever he or she sets out to accomplish and can thus successfully meet one's goals (Utsch et al. 1999; Zhao et al. 2005). This belief that one can achieve whatever goals he or she sets-particularly, that one can successfully start and manage a business (i.e., entrepreneurial self-efficacy [Chen et al. 1998])—may 
make people more likely to disengage their pro-environmental values for several reasons.

Self-regulation centers on the notion that people do things that "give them satisfaction and a sense of self-worth, and they refrain from behaving in ways that violate their moral standards because such conduct will bring self-condemnation" (White et al. 2009: 42). People's feelings of satisfaction and self-worth typically improve when they take on tasks they believe they can accomplish, and actually completing those tasks further improves their perceived competence (Ryan and Deci 2000, 2001). Consequently, "self-efficacy beliefs function as an important set of proximal determinants of human self-regulation" (Bandura 1991: 257). In terms of entrepreneurship, entrepreneurial self-efficacy denotes one's belief that he or she is able to perform the tasks involved in starting and successfully managing a venture (Chen et al. 1998). Indeed, researchers have found that entrepreneurial self-efficacy is positively related to the intention to act entrepreneurially (Zhao et al. 2005; Zhao et al. 2010) and to entrepreneurial action (Boyd and Vozikis 1994).

While one important entrepreneurial task (i.e., innovation) includes developing new ideas, products, processes, and markets, the other activities representing the subcomponents of entrepreneurial self-efficacy are associated with effective opportunity exploitation (Chen et al. 1998). Individuals are usually attracted to activities they can competently complete (Bandura and Schunk 1981; Ryan and Deci 2000), and people with high self-efficacy are frequently drawn to challenging tasks that test and develop their skills (Csikszentmihalyi 1978) as well as to experiences that offer personal fulfillment (Srivastava et al. 2010). After all, such people believe-often passionately-that they can successfully complete these challenging tasks. Thus, when presented with opportunities that could damage the natural environment, individuals with high entrepreneurial self-efficacy frequently want to seize the chance to utilize their capabilities to actively exploit them. Still, as mentioned above, individuals' moral values may ultimately limit such actions. As a result, in such situations, individuals are confronted with a conflict between actions that will enhance their satisfaction and self-worth but will concurrently breach their moral guidelines and lead to self-censure. As Bandura (2006: 171) stated, "selective moral disengagement is most likely to occur under moral predicaments in which detrimental conduct brings valued outcomes."

For individuals with low entrepreneurial self-efficacy, in contrast, there is minimal tension between satisfaction and self-worth on the one hand and moral values on the other when evaluating the appeal of opportunities 
that cause harm to the natural environment. Such individuals have doubts about whether the benefits of such opportunities will pan out because they are not confident in their ability to successfully exploit them. In general, people with low self-efficacy are easily deterred by obstacles (Gist 1987), which-in this context-could include their own pro-environmental values. Such individuals are also likely to feel that they have minimal control over the entrepreneurial situation and outcomes (Markman et al. 2002).

\section{Perceived Industry Munificence}

Individuals exercise agency through self-efficacy and within the bounds of system conditions (Bandura 1991). System conditions refer to "the changeability or controllability of the environment ... [and represent] the opportunity structures to exercise personal efficacy and the ease of access to those opportunity structures" (Bandura 1991: 269). A significant system condition for entrepreneurs is the industry, specifically industry munificence, or the "scarcity or abundance of critical resources needed by (one or more) firms operating within an environment" (Castrogiovanni 1991: 542; cf. Dess and Beard 1984).

Some industries have plentiful resources and represent a decision context in which poor and good judgments lead to similar outcomes. In other words, in such cases, high levels of industry munificence can make up for entrepreneurial and strategic weaknesses (Tsai et al. 1991). Due to their greater environmental capacity, munificent environments support growth and stability and allow businesses to develop a cushion in case of future hardship (Dess and Beard 1984). In fact, some have described these resource-rich industries as producing a tide that raises all boats (Wasserman et al. 2001). Less munificent environments (i.e., industries with less environmental capacity) (Dess and Beard 1984), on the other hand, are characterized by intense competition (Aldrich 1979), few exploitable opportunities (Covin and Slevin 1989), and hostility (Khandwalla 1976, 1977; Miller and Friesen 1983). Consequently, these resource-poor industries are more "selective," and decision makers' choices have a stronger influence on performance outcomes than in more munificent industries (Covin and Slevin 1989; Tushman 1977; Zahra and Covin 1995). Thus, there are likely to be higher personal agency beliefs in environments individuals perceive as being less munificent (in comparison to environments perceived as being more munificent) because people are more likely to feel that decisions will have a greater influence on relevant outcomes (including preventing unwanted performance outcomes). 
The industry munificence individuals perceive may directly affect how much they disengage their pro-environmental values. Firms in munificent industries can grow and profit in a variety of ways (Brittain and Freeman 1980; Tushman and Anderson 1986). Thus, acting on opportunities that damage the natural environment is likely to be only one of many means to improve firm performance. Additionally, individuals may view opportunity exploitation itself as an unreasonably risky way to enhance firm performance (Covin and Slevin 1989). As a result, there is minimal conflict between the cost of passing up an opportunity and the values underlying one's assessment. Thus, under perceived conditions of munificence, individuals tend to keep their pro-environmental values fully engaged, and there is a lower likelihood that entrepreneurs will be attracted to opportunities that could cause harm to the natural environment.

In contrast, industries with less munificence are characterized by a "paucity of readily exploitable market opportunities" (Zahra and Covin 1995: 48) and very limited maneuverability. In these environments, businesses have fewer means to improve growth and profitability. This means that opportunities that could cause damage to the natural environment are part of a substantially smaller set of opportunities that could be pursued. Indeed, scholars have found that corporate entrepreneurship plays a more salient role in firm performance in resource-scarce industries than in industries with greater munificence (Covin and Slevin 1989; Miller and Friesen 1983; Zahra and Covin 1995). Therefore, when individuals perceive an industry as being less munificent, the importance of pursuing an opportunity that may harm the environment is likely to conflict with their pro-environmental values more than in more munificent contexts. In turn, this increased conflict between values and beliefs about outcomes makes decision makers more likely to disengage their values when evaluating opportunities. Such decision makers, for instance, may claim that after developing the environmentally unfriendly opportunity and/or when the industry improves, they will be better positioned to pursue only environmentally friendly opportunities in the future.

\section{Individual Values and EnTrepreneurial Motivation}

Although the search for a direct association between personality traits and entrepreneurship has led to an unclear picture, the entrepreneur is clearly an essential part of the entrepreneurial process (Shook et al. 2003). During the recent revival of studies on entrepreneurs' personal characteristics, 
scholars have gone past looking for "trans-situational consistency in personality traits" (Shaver and Scott 2002) and have begun exploring deeper models of individual characteristics, motivation, cognition, and behavior (e.g., Baron 2004; Baum and Locke 2004; Baum et al. 2001; Busenitz and Barney 1997; Mitchell et al. 2004; Rauch and Frese 2007; Zhao et al. 2005). Take, for example, Baum et al. (2001) and Baum and Locke (2004) who showed individual characteristics such as tenacity and passion do not have a direct association with new firm growth but that these variables are associated with growth-related motivation. In addition, Rauch and Frese (2007) and Zhao and Seibert (2006) used meta-analyses to illustrate the necessity for researchers to explore more proximal moderators and mediators instead of the direct association between individual characteristics and entrepreneurial outcomes. A stronger understanding of the association between entrepreneurs and proximal outcomes, including cognition, motivation, and decision making, is likely to yield a more vivid and comprehensive view of the entrepreneurial process (Shane et al. 2003). We examine in this section how personal values motivate entrepreneurial decisions. We explore personal values since extant literature on psychology finds that one's values and his or her choices among alternatives are closely connected (Feather 1990). Therefore, a focus on personal values offers a comprehensive framework for studying decisions (Rohan 2000).

Personal values are at the core of motivated choice (Judge and Bretz 1992). Values constitute the lens through which individuals view potential actions, including how attractive these actions are. As such, personal value priorities generate valences (i.e., desirability) for prospective outcomes (Feather 1982) and "cause decisions" (Rohan 2000: 270). Thus, individuals' values influence how they define situations, evaluate alternative possibilities, and finally decide on a course of action. As entrepreneurs decide on an entrepreneurial endeavor, it is highly likely that the weight they place on the attractiveness of a successful outcome will (to some extent) depend on their personal values (Holland and Shepherd 2013).

Individuals' values stem from their cognitive representations of fundamental needs (Rokeach 1973; Schwartz 1992). Although scholars have studied values for many decades, Milton Rokeach (1973) is generally credited with starting a stream of research on values with his Rokeach Value Survey. Rokeach's work drew on the assumption that a finite number of “terminal human values" serve as individuals' internal reference points, which are the basis for judgment and motivation (Rohan 2000). Expanding Rokeach's (1973) work, Schwartz (1992) built a more comprehensive 
theory of values. This theory comprises an overarching structure for the value system. The theory predicts decisions and actions in numerous practical situations (Bardi et al. 2008). We call upon individual-level Schwartz values theory (1992) in this chapter. According to Schwartz (1992), there are ten basic universal value types. These value types include power, achievement, hedonism, stimulation, self-direction, universalism, benevolence, tradition, conformity, and security. Based on the differences and similarities between these values' motivational structures, Schwartz (1992) outlined four higher-order value types, specifically openness to change, self-transcendence, self-enhancement, and conservation. Higher-order values are organized in a circular manner such that adjacent values will have motivational commonalities whereas values on opposite sides of the circle will have motivations that are not compatible. While Schwartz (1992) does not expect opposing values to be negatively correlated, if an individual holds opposing values at the same time, conflicting motivations may increase internal conflict during the decision-making process (Schwartz 1992). Researchers have empirically verified that the theoretical structure of Schwartz's value types is reliable and can be generalized to various samples (Morris et al. 1998). Due to this integrated value structure, researchers can explore how related value sets impact the desirability of the financial and non-financial returns, as well as switching costs, associated with persisting with entrepreneurship (Feather 1995).

\section{Self-Enhancement}

In regard to the four higher-order values, self-enhancement comprises the values of power, achievement, and hedonism. These values center on developing one's own interests-even if it is associated with costs for others (Schwartz 1992). Thus, entrepreneurs high in self-enhancement will strive for extreme success of their ventures because they want to gain social status and recognition. These individuals are frequently prepared to dedicate substantial time and energy to display ability and success in what they are doing (Bardi and Schwartz 2003). Individual with high levels of selfenhancement generally relish in having control over resources and employees, and they recognize that creating a flourishing business can lead to a positive public image and prominent positions in society (Scheinberg and MacMillan 1988).

In the business context, achievement and power are usually associated with a firm's financial performance, often generating higher incomes and 
wealth. Individuals who value self-enhancement may obtain satisfaction from the opportunities for self-indulgence available to the wealthy. Looking beyond merely fulfilling their basic needs, such people are likely to seek out opportunities that satisfy wants and luxuries (Bardi et al. 2008). Indeed, many entrepreneurs maintain that the potential for high financial income and recognition are primary motivations for entering into an entrepreneurial career (Carter et al. 2003; Kuratko et al. 1997). Thus, for individuals who value power, achievement, and self-indulgence, financial returns are likely to play a more significant role in decisions regarding the attractiveness of an entrepreneurial career than for individuals who emphasize selfenhancement values to a lesser extent (Holland and Shepherd 2013).

\section{Openness to Change}

The values comprising openness to change include stimulation, hedonism, and self-direction. People who appreciate openness favor independent thought and action and derive joy from life's challenge and excitement (Schwartz 1992). These people like to try new approaches and are not scared of challenging and ultimately eliminating traditional roles or systems. In addition, individuals who are open to change find learning stimulating and enjoy using their intellectual capabilities to create innovative products (Shane et al. 1991). They also tend to have a higher promotion focus in terms of their self-regulatory system. They often seek growth and improvement toward their ideal selves (Brockner et al. 2004). Thus, people who value openness to change will emphasize the non-financial benefits of entrepreneurial action, such as self-realization and learning through experience.

People who appreciate self-enhancement and people who appreciate openness to change share the value of hedonism. Yet, they go about gratifying their desires and seeking pleasure in different ways (Schwartz 1992). Individuals who value self-enhancement receive greater satisfaction from power and achievement, whereas those who value openness to change explore new experiences and the autonomy to set their own objectives (Bardi et al. 2008). In addition, entrepreneurs drawing on openness as a principle guiding their lives will find pleasure in the freedom provided by their entrepreneurial career (Carter et al. 2003). Liberty to control one's own schedule and work life and the chance to wear many "different hats" produces psychic benefits that many entrepreneurs value as much (or more) than financial rewards. Thus, entrepreneurs who value openness to change are likely to emphasize these types of 
non-economic benefits from entrepreneurial action in their decisionmaking process more than individuals who do not value openness (Holland and Shepherd 2013).

\section{Self-Transcendence}

The values that comprise self-transcendence include universalism and benevolence. Universalism and benevolence are similar in that they both focus on others. However, universalism is typically associated with individuals outside one's close contact circle, whereas benevolence is associated with individuals inside that person's close environment (Bardi et al. 2008). These self-transcendence values inspire individuals to move beyond self-centered interests toward bettering the lives of others including personal acquaintances, their colleagues, communities in which they live, and the world overall (Schwartz 1992). People who hold these values tend to focus on being helpful, honest, and loyal to people they interact with and thrive when they have positive relationships with other individuals (Mikulincer et al. 2003). These people are inspired and motivated by enhancing their associates' lives, and they revel in the psychological benefits they receive from such benefitting others (Lyons et al. 2007).

Individuals with high self-transcendence values are likely to engage in social entrepreneurship (Hemingway 2005). These individuals may be motivated to start new ventures that encourage equal opportunities for everyone, environmental protection, better standards of living in developing nations, or other social improvements. In starting new ventures to solve such problems, self-transcendent entrepreneurs may obtain fulfillment from having an enduring positive effect on the lives of their stakeholders including employees and customers. As such, individuals with high self-transcendence values are likely to stress these forms of nonfinancial benefits in their entrepreneurial decisions more than those with low self-transcendence values (Holland and Shepherd 2013).

\section{Conservation}

The values associated with conservation comprise tradition, conformity, and security (Schwartz 1992). Individuals who appreciate conservation are generally committed to longstanding standards, ideals, and traditions and value societal stability, preservation of customs, and moderation in action (Schwartz 1992). For example, job applicants high in conservation 
value family ownership of a potential employer more than those low in conservation because family ownership is typically associated with the stability and tradition of the firm (Hauswald 2013). Thus, entrepreneurs with high conservation values will tend to prioritize stability when starting their ventures. Personal and/or family security can be another motivator behind such individuals' decision to start or persist with a venture (Kuratko et al. 1997). These people will stress self-control and caution in their actions and are likely to maintain the status quo, often keeping with conventional roles while they at the same time strive for harmonious relationships with others (Lyons et al. 2007). Additionally, individuals with high conservation values tend to attend to societal norms and generally perceive an obligation to meet responsibilities (Egri and Herman 2000). Therefore, entrepreneurs with high conservation values are also more likely to have a prevention regulatory focus, seeking to lessen discrepancies with their "ought" selves by avoiding change because they fear that change can yield negative results (Brockner et al. 2004). As such, they often focus on the potential costs of change when they decide about entrepreneurial issues.

Staw (1981) states that shared norms for consistency can result in the preference to remain dedicated to a chosen course of action even if it is failing than be seen as someone who gives up or is unable to make decisions. Staying consistent is an involuntary reaction that can enhance an individual's feeling of security in challenging situations (DeTienne et al. 2008). Because individuals with high conservation values like to maintain customs and norms, they are likely to be especially vulnerable to norms of consistency and to thus stress the costs associated with switching opportunities in their decisions to persist with their entrepreneurial endeavor (Holland and Shepherd 2013).

\section{Motivation to Persist with Entrepreneurial Action}

Researchers have studied and tested the motivation to justify previous decisions at length (Baron 1998; Keil 1995), generally referring to this topic using self-justification theory (Staw and Fox 1977). Self-justification theory is largely based on Festinger's (1957) theory of cognitive dissonance and argues that "individuals will bias their attitudes on a task in a positive direction so as to justify their previous behavior" (Staw 1981: 579 ). Thus, people frequently decide to continue with a course of action because they want to demonstrate to themselves (psychological selfjustification) and to other people (social self-justification) their rationality and competence (Keil et al. 2000b). 


\section{Personal Sunk Costs Driving Persistence}

One signal of the motivation to justify previous decisions is the top decision maker's personal sunk costs. Not only do entrepreneurs frequently invest financial resources in their ventures, but they also tend to dedicate considerable time and effort to their firms (Arkes and Blumer 1985). Their reputation may be intimately connected to their venture, thus leading to psychological or social self-justifications. While the resources an entrepreneur has already devoted to his or her firm are sunk costs and should thus be not relevant for decisions concerning the present or the future, they may actually add to a person's need for self-justification.

More specifically, sunk costs are "costs that have occurred in the past and cannot be changed by any current or future action" (Devine and O'Clock 1995) and "create a cognitive bias at a subconscious level which may be manifested in the form of emotional attachment" (Keil et al. 2000a, b). The psychological attachment associated with sunk costs may stem from individuals' need to defend previous behavior and to appear competent to others. For instance, Dean et al. (1997) showed that at the industry level, the exit rate of new ventures is negatively associated with sunk cost levels. We propose that this form of emotional attachment may also occur with entrepreneurs such that persistence in a venture will be positively associated with the level of the entrepreneurs' personal sunk costs. In this sense, sunk costs can be seen as an obstruction to exit for failing ventures and can change the exit threshold from involving only financial information to also including the need to overcome sunk costs in order to exit (Caves and Porter 1977; Rosenbaum and Lamort 1992).

\section{Personal Self-Interest}

Personal self-interest is another form of self-justification. Researchers (Graebner and Eisenhardt 2004; Jensen and Meckling 1976) have provided evidence suggesting that people tend to make decisions based on their own self-interest. Agency theory (Jensen and Meckling 1976), which deals with goal incongruency between a principal and an agent, sheds light on this notion of self-interest: "Under agency theory, goal incongruency between principal and agent can create a situation in which the agent acts to maximize his or her own utility, rather than acting in the best interests of the principal" (Keil et al. 2000a: 636). In relation to self-interest, a similar situation arises: an entrepreneur aims to maximize his or her own utility, which can result in cognitive biases regarding the firm's best 
interests. Such a situation frequently leads to self-justification. For instance, an entrepreneur who enjoys skiing wants to build a plant near a worldclass ski region, thus deciding in line with his or her self-interest. The entrepreneur can defend this decision based on the firm's needs (e.g., it would be better to entertain important stakeholders) even when it is obvious that a less costly location would be more prudent.

\section{Personal Opportunities}

A third trigger of motivation for self-justification might result from the personal opportunities available to the entrepreneur. Cognitive psychology research (Kanfer 1990) suggests that a key aspect of motivation is being able to choose among alternative courses of action. Thus, a key motivational source for entrepreneurs could be personal opportunities they have available to them (e.g., education, other jobs, retirement), which may in turn influence the decisions they make about persistence with their venture. The literature on turnover has shown that alternative employment options play a significant role in employees leaving the organization (Jackofsky and Peters 1983; March and Simon 1958), and Graebner and Eisenhardt (2004) showed that CEOs with strong personal motivations have a higher probability of selling their firm. Similarly, McGrath (1999: 14) argued that "an entrepreneur might disband an economically profitable business if other activities appear more lucrative or interesting, if his or her interests change or if it seems that long-run growth is limited," which suggests that the motivation for persistence at least partially depends on the alternative opportunities entrepreneurs have available to them. When alternatives are available, individuals may choose the most attractive option for their own life regardless of whether that option is in their firm's best interests. On the other hand, if no alternatives outside their current firm are available or the alternatives are unattractive, entrepreneurs are more likely to persist with their current firm.

\section{Norms for Consistency}

Norms for consistency-or the notion that people continue with a course of action purely because they feel that remaining consistent is the most suitable option (Cialdini 1993; Staw and Ross 1980) — are an additional factor influencing individuals' commitment to a particular action plan (Staw 1981) and can therefore motivate entrepreneurs' persistence. As Cialdini 
argued (1993: 53), "Because it is a preprogrammed and mindless method of responding, automatic consistency can supply a safe hiding place from troubling realizations." Thus, entrepreneurs can search for signals within the venture indicating that persistence is the most appropriate policy and disregard information implying that adaptation is needed. Two important signals are a venture's prior success and the entrepreneur's perceptions of the venture's collective efficacy.

\section{Prior Organizational Success}

Having prior success may be another motivator of persistence when entrepreneurs believe that success is close by and that they merely need to "ride out the storm" to achieve it. Indeed, scholars have found that previous organizational success can lead to strategic persistence (Audia et al. 2000; Lant et al. 1992). Audia et al. (2000: 849), for instance, showed that "Once organizations achieve success, their natural tendency is to continue to exploit the strategies that worked in the past." Similarly, in a study on real options, McGrath (1999) highlighted three key arguments why prior success can encourage persistence. First, entrepreneurs often oversample success while simultaneously undersampling failure. In addition, prior success can lead to the underestimation of risks and overestimation of projected successes (Levinthal and March 1993: 105), thus causing them to believe that their perseverance will ultimately lead to additional successes. Second, previous success can encourage persistence because "organizations code outcomes into successes and failures and develop ideas about causes for them" (Levinthal and March 1993: 97). Stemming from their own cognitive biases, entrepreneurs often believe that their successes result from their own actions whereas failures are caused by bad luck (Staw et al. 1983). Attribution theory scholars (e.g., Shaver et al. 2001) argue that people often try to internalize success-believing that any success is the result of their own efforts-and externalize failure. Thus, entrepreneurs are likely to believe that prior success resulted from specific decisions that were made and/or from resources that were available rather than from some outside source. Therefore, the firm again will be successful in the future. Third, prior success often lessens a firm's willingness to change routines or technologies even when such changes come with added benefits (Levitt and March 1988; McGrath 1999). As such, prior success seems to make entrepreneurs more complacent and satisfied with their present situation; these entrepreneurs are less keen to make needed adaptations, thereby motivating persistence. 


\section{Perceived Collective Efficacy}

Furthermore, norms for consistency may "be determined by the cultural and organizational norms surrounding individuals" (Staw 1981: 335). One organizational norm that appears to play a particularly important role in persistence decisions is collective efficacy-or a group's collective belief that it can effectively perform a specific task. According to Bandura (1986: 449), "Perceived collective efficacy will influence what people choose to do as a group, how much effort they put into it, and their staying power when group efforts fail to produce results."

While collective efficacy research is still quite new, researchers (e.g., Bandura 1986: 449) argue that "collective efficacy is rooted in self-efficacy" and therefore should function in a similar way. In a meta-analysis of research on the association between self-efficacy and persistence outcomes, Multon et al. (1991) showed that self-efficacy and persistence are positively correlated. This positive association was found across a broad range of participants, experimental designs, and measurement approaches. Furthermore, at the level of the group, scholars have shown that groups with high collective efficacy are more likely to persist than groups with low collective efficacy (e.g., Hodges and Carron 1992; Little and Madigan 1997). Entrepreneurs working in settings where collective efficacy (e.g., of the entrepreneurial team) is high are therefore likely to be more motivated to persist with their venture than those working in settings with low collective efficacy.

\section{Extrinsic Motivation}

Economic theory researchers of firm exit assert that underperforming firms should not exist; instead, they should be exited or be eliminated from the environment. However, empirical studies provide evidence that such firms persist, sometimes with no end in sight (e.g., Gimeno et al. 1997). Earlier, we discussed potential determinants of persistence in underperforming firms, but a question still remains: why do some entrepreneurs' persistence decisions align with rational economic views whereas others do not? To explain differences among entrepreneurs' persistence decisions, we look to a core assumption of the economics-based model: extrinsic motivation.

Frequently conceptualized in research as financial income and personal wealth (Kuratko et al. 1997), extrinsic motivation refers to "a cognitive state reflecting the extent to which an individual attributes the force of his or her task behaviors to some extrinsic outcome" (Brief and Aldag 1977: 497). Researchers have long recognized the possibility of receiving a financial 
reward as a significant motivator for entrepreneurial behavior (Campbell 1992; Kuratko et al. 1997; Schumpeter 1961; Shepherd and DeTienne 2005). As an early example, Schumpeter (1961) proposed that empire building with the goal of gaining financial reward is a salient motivation for entrepreneurs. Further, Campbell's (1992) economic perspective on entrepreneurship suggests that a person decides to enter entrepreneurship in case the present value of profit he or she expects from entrepreneurship is greater than the expected profit from being an employee. My (Dean) colleague and I (Shepherd and DeTienne 2005) showed that potential financial rewards motivate entrepreneurs to recognize opportunities (in particular entrepreneurs with low levels of prior knowledge), and Kuratko et al. (1997: 31) revealed that "extrinsic goals concentrating on wealth" play a crucial role in sustaining entrepreneurial behavior.

Yet, there is a lack of research exploring extrinsic motivation's influence on persistence. The literatures on job satisfaction and turnover could provide useful insights to better explain this relationship. Research has repeatedly shown that there is a negative association between pay satisfaction and employee turnover (for a meta-analytic review, see Cotton and Tuttle 1986) and a positive association between job satisfaction and commitment to the organization (Johnston et al. 1990). Such research has shown that people who are happy with the financial income they receive from their job are not only less likely to leave the firm but also tend to have higher organizational commitment. The degree to which an organization meets an individual's expectations affects how committed he or she is toward the organization (Babakus et al. 1996). Thus, for the context at hand, individuals with lower extrinsic motivation are likely to be content with an underperforming firm, whereas individuals with high extrinsic motivation are likely to be less content with an underperforming firm. As with job satisfaction, people who are content in their organization are less motivated to leave.

\section{CONCLUSION}

In this chapter, we explored why some people are more motivated than others to engage in and persist with entrepreneurship. We found that while some motivators appear to trigger entrepreneurial action more generally (e.g., financial rewards or certain individual values), other types of motivation seem to stimulate a specific type of entrepreneurship (e.g., empathy motivating entrepreneurial action targeted toward developing 
societies). Interestingly, the inability to pursue a career as a salaried employee (e.g., due to injury or psychological disorder) can also stimulate entrepreneurial motivation. Finally, a key finding is that the effects of prior knowledge as described in Chap. 2 and those of motivation as described in this chapter do not seem to be independent of each other but can conjointly motivate entrepreneurial action.

\section{Note}

1. Fear of failure can also be associated with motivating action (Cacciotti et al. 2016).

\section{REFERENCES}

Abbey, A., \& Dickson, J. W. (1983). R\&D work climate and innovation in semiconductors. Academy of Management Journal, 26(2), 362-368.

Agle, B. R., Mitchell, R. K., \& Sonnenfeld, J. A. (1999). Who matters to Ceos? An investigation of stakeholder attributes and salience, corporate performance, and CEO values. Academy of Management Journal, 42(5), 507-525.

Akande, A. (1994). Coping with entrepreneurial stress: Evidence from Nigeria. Journal of Small Business Management, 32(1), 83.

Aldrich, H. E. (1979). Organizations and environments. Englewood Cliffs: Prentice-Hall, 40(3), 437-453.

Alon, I., \& Lerner, M. (2008). International entrepreneurship in China: Lessons from global entrepreneurship monitor. Cell, 407, 913-8842.

Amabile, T. M. (1993). Motivational synergy: Toward new conceptualizations of intrinsic and extrinsic motivation in the workplace. Human Resource Management Review, 3(3), 185-201.

Amabile, T. M. (1997). Motivating creativity in organizations: On doing what you love and loving what you do. California Management Review, 40(1), 39-58.

Amato, P. R. (2005). The impact of family formation change on the cognitive, social, and emotional well-being of the next generation. The Future of Children, $15,75-96$.

Amit, R., Glosten, L., \& Muller, E. (1990). Entrepreneurial ability, venture investments, and risk sharing. Management Science, 36(10), 1233-1246.

Ardichvili, A., Cardozo, R., \& Ray, S. (2003). A theory of entrepreneurial opportunity identification and development. Journal of Business Venturing, 18(1), $105-123$.

Arkes, H. R., \& Blumer, C. (1985). The psychology of sunk cost. Organizational Behavior and Human Decision Processes, 35(1), 124-140. 
Arnold, N. L., \& Seekins, T. (2002). Self-employment: A process for use by vocational rehabilitation agencies. Journal of Vocational Rehabilitation, 17(2), 107-113.

Ashford, S. J. (1986). Feedback-seeking in individual adaptation: A resource perspective. Academy of Management Journal, 29(3), 465-487.

Audia, P. G., Locke, E. A., \& Smith, K. G. (2000). The paradox of success: An archival and a laboratory study of strategic persistence following radical environmental change. Academy of Management Journal, 43(5), 837-853.

Austin, J., Stevenson, H., \& Wei-Skillern, J. (2006). Social and commercial entrepreneurship: Same, different, or both? Entrepreneurship Theory and Practice, $30,1-22$.

Babakus, E., Cravens, D. W., Johnston, M., \& Moncrief, W. C. (1996). Examining the role of organizational variables in the salesperson job satisfaction model. Journal of Personal Selling \& Sales Management, 16(3), 33-46.

Baker, T., \& Nelson, R. E. (2005). Creating something from nothing: Resource construction through entrepreneurial bricolage. Administrative Science Quarterly, $50(3), 329-366$.

Bandura, A. (1986). Social cognitive theory. Englewood Cliffs: Prentice-Hall, 34(2), 169-178.

Bandura, A. (1991). Social cognitive theory of self-regulation. Organizational Behavior and Human Decision Processes, 50(2), 248-287.

Bandura, A. (2006). Toward a psychology of human agency. Perspectives on Psychological Science, 1(2), 164-180.

Bandura, A., \& Schunk, D. H. (1981). Cultivating competence, self-efficacy, and intrinsic interest through proximal self-motivation. Journal of Personality and Social Psychology, 41(3), 586.

Bardi, A., \& Schwartz, S. H. (2003). Values and behavior: Strength and structure of relations. Personality and Social Psychology Bulletin, 29(10), 1207-1220.

Bardi, A., Calogero, R. M., \& Mullen, B. (2008). A new archival approach to the study of values and value - Behavior relations: Validation of the value lexicon. Journal of Applied Psychology, 93(3), 483.

Baron, R. A. (1998). Cognitive mechanisms in entrepreneurship: Why and when entrepreneurs think differently than other people. Journal of Business Venturing, 13(4), 275-294.

Baron, R. A. (2004). The cognitive perspective: A valuable tool for answering entrepreneurship's basic “why” questions. Journal of Business Venturing, 19(2), 221-239.

Baron, R. A. (2006). Opportunity recognition as pattern recognition: How entrepreneurs "connect the dots" to identify new business opportunities. Academy of Management Perspectives, 20(1), 104-119.

Baron, R. A. (2008). The role of affect in the entrepreneurial process. Academy of Management Review, 33(2), 328-340. 
Bartol, K. M., \& Martin, D. C. (1998). Performance appraisal: Maintaining system effectiveness. Public Personnel Management, 27(2), 223-230.

Batavia, A. I., \& Schriner, K. (2001). The Americans with disabilities act as engine of social change: Models of disability and the potential of a civil rights approach. Policy Studies Journal, 29(4), 690-702.

Batson, C. D., \& Shaw, L. L. (1991). Evidence for altruism: Toward a pluralism of prosocial motives. Psychological Inquiry, 2(2), 107-122.

Baum, J. R., \& Locke, E. A. (2004). The relationship of entrepreneurial traits, skill, and motivation to subsequent venture growth. Journal of Applied Psychology, 89(4), 587.

Baum, J. R., Locke, E. A., \& Smith, K. G. (2001). A multidimensional model of venture growth. Academy of Management Journal, 44(2), 292-303.

Baumol, W. J. (1990). Entrepreneurship: Productive, unproductive, and destructive. Journal of Political Economy, 98(5, Part 1), 893-921.

Beck, A. T., \& Clark, D. A. (1997). An information processing model of anxiety: Automatic and strategic processes. Behaviour Research and Therapy, 35, 49-58.

Birley, S., \& Westhead, P. (1994). A taxonomy of business start-up reasons and their impact on firm growth and size. Journal of Business Venturing, 9(1), 7-31.

Boyd, N. G., \& Vozikis, G. S. (1994). The influence of self-efficacy on the development of entrepreneurial intentions and actions. Entrepreneurship Theory and Practice, 18, 63-63.

Breugst, N., Domurath, A., Patzelt, H., \& Klaukien, A. (2012). Perceptions of entrepreneurial passion and employees' commitment to entrepreneurial ventures. Entrepreneurship Theory and Practice, 36(1), 171-192.

Brief, A. P., \& Aldag, R. J. (1977). The intrinsic-extrinsic dichotomy: Toward conceptual clarity. Academy of Management Review, 2(3), 496-500.

Brittain, J. W., \& Freeman, J. H. (1980). Organizational proliferation and density dependent selection. In J. Kimberly \& R. H. Miles (Eds.), The organizational life cycle (pp. 291-338). San Francisco: Jossey-Bass.

Brockner, J., Higgins, E. T., \& Low, M. B. (2004). Regulatory focus theory and the entrepreneurial process. Journal of Business Venturing, 19(2), 203-220.

Brown, T. E., Davidsson, P., \& Wiklund, J. (2001). An operationalization of Stevenson's conceptualization of entrepreneurship as opportunity-based firm behavior. Strategic Management Journal, 22(10), 953-968.

Burgelman, R. A., \& Välikangas, L. (2005). Managing internal corporate venturing cycles. MIT Sloan Management Review, 46(4), 26.

Busenitz, L. W., \& Barney, J. B. (1997). Differences between entrepreneurs and managers in large organizations: Biases and heuristics in strategic decisionmaking. Journal of Business Venturing, 12(1), 9-30.

Byrne, O., \& Shepherd, D. A. (2015). Different strokes for different folks: Entrepreneurial narratives of emotion, cognition, and making sense of business failure. Entrepreneurship Theory and Practice, 39(2), 375-405. 
Cacciotti, G., \& Hayton, J. C. (2015). Fear and entrepreneurship: A review and research agenda. International Journal of Management Reviews, 17(2), 165-190.

Cacciotti, G., Hayton, J. C., Mitchell, J. R., \& Giazitzoglu, A. (2016). A reconceptualization of fear of failure in entrepreneurship. Journal of Business Venturing, 31(3), 302-325.

Callahan, M., Shumpert, N., \& Mast, M. (2002). Self-employment, choice and self-determination. Journal of Vocational Rehabilitation, 17(2), 75-85.

Campbell, C. A. (1992). A decision theory model for entrepreneurial acts. Entrepreneurship: Theory and Practice, 17(1), 21-28.

Campbell, J. P., \& Pritchard, R. D. (1976). Motivation theory in industrial and organizational psychology. In M. Dunnette (Ed.), Handbook of industrial and organizational psychology. Chicago: Rand McNally, 12(3), 405-424.

Cardon, M. S., Wincent, J., Singh, J., \& Drnovsek, M. (2009). The nature and experience of entrepreneurial passion. Academy of Management Review, 34(3), $511-532$.

Cardon, M. S., Stevens, C. E., \& Potter, D. R. (2011). Misfortunes or mistakes?: Cultural sensemaking of entrepreneurial failure. Journal of Business Venturing, 26(1), 79-92.

Cardon, M. S., Foo, M. D., Shepherd, D., \& Wiklund, J. (2012). Exploring the heart: Entrepreneurial emotion is a hot topic. Entrepreneurship Theory and Practice, 36(1), 1-10.

Carroll, C. D., Hall, R. E., \& Zeldes, S. P. (1992). The buffer-stock theory of saving: Some macroeconomic evidence. Brookings Papers on Economic Activity, $1992(2), 61-156$.

Carter, S. (2011). The rewards of entrepreneurship: Exploring the incomes, wealth, and economic well-being of entrepreneurial households. Entrepreneurship Theory and Practice, 35(1), 39-55.

Carter, N. M., Gartner, W. B., Shaver, K. G., \& Gatewood, E. J. (2003). The career reasons of nascent entrepreneurs. Journal of Business Venturing, 18(1), 13-39.

Castrogiovanni, G. J. (1991). Environmental munificence: A theoretical assessment. Academy of Management Review, 16(3), 542-565.

Caves, R. E., \& Porter, M. E. (1977). From entry barriers to mobility barriers: Conjectural decisions and contrived deterrence to new competition. Quarterly Journal of Economics, 91, 241-261.

Chen, C. C., Greene, P. G., \& Crick, A. (1998). Does entrepreneurial self-efficacy distinguish entrepreneurs from managers? Journal of Business Venturing, 13(4), 295-316.

Cialdini, R. (1993). The psychology of influence. New York: William Morrow \& Co.

Cohen, W. M., \& Levinthal, D. A. (1990). Absorptive capacity: A new perspective on learning and innovation. Administrative Science Quarterly, 35, 128-152. 
Conroy, D. E. (2001). Progress in the development of a multidimensional measure of fear of failure: The performance failure appraisal inventory (PFAI). Anxiety, Stress and Coping, 14(4), 431-452.

Conroy, D. E. (2004). The unique psychological meanings of multidimensional fears of failing. Journal of Sport and Exercise Psychology, 26(3), 484-491.

Conroy, D. E., Willow, J. P., \& Metzler, J. N. (2002). Multidimensional fear of failure measurement: The performance failure appraisal inventory. Journal of Applied Sport Psychology, 14(2), 76-90.

Cotton, J. L., \& Tuttle, J. M. (1986). Employee turnover: A meta-analysis and review with implications for research. Academy of Management Review, $11(1)$, $55-70$.

Covin, J. G., \& Slevin, D. P. (1989). Strategic management of small firms in hostile and benign environments. Strategic Management Journal, 10(1), 75-87.

Csikszentmihalyi, M. (1975). Play and intrinsic rewards. Journal of Humanistic Psychology, 15(3), 41-63.

Csikszentmihalyi, M. (1978). Intrinsic rewards and emergent motivation. In The hidden costs of reward: New Perspectives on the Psychology of Human Motivation (pp. 205-216). Hillsdale: Lawrence Erlbaum Associates.

Csikszentmihalyi, M. (2000). Beyond boredom and anxiety. San Francisco: JosseyBass, 125(2), 276-302.

Cummings, L. L., \& O'Connell, M. J. (1978). Organizational innovation: A model and needed research. Journal of Business Research, 6(1), 33-50.

Curran, T., Hill, A. P., Appleton, P. R., Vallerand, R. J., \& Standage, M. (2015). The psychology of passion: A meta-analytical review of a decade of research on intrapersonal outcomes. Motivation and Emotion, 39(5), 631-655.

Daily, G. (1997). Nature's services: Societal dependence on natural ecosystems. Washington, DC: Island, 387(6630), 253-260.

Davis, M. H. (1996). Empathy: A social psychological approach. Boulder: Westview Press, 2, 113-126.

Dean, T. J., Turner, C. A., \& Bamford, C. E. (1997). Impediments to imitation and rates of new firm failure. In Academy of management proceedings (pp. 103-107). Academy of Management.

Deci, E. L., \& Ryan, R. M. (1985). The general causality orientations scale: Selfdetermination in personality. Journal of Research in Personality, 19(2), 109-134.

Deci, E. L., \& Ryan, R. M. (2001). On happiness and human potentials: A review of research on hedonic and eudaimonic well-being. Annual Review of Psychology, 52(1), 141-166.

Dentener, F., Drevet, J., Lamarque, J. F., Bey, I., Eickhout, B., Fiore, A. M., et al. (2006). Nitrogen and sulfur deposition on regional and global scales: A multimodel evaluation. Global Biogeochemical Cycles, 20(4), 1-21.

Dess, G. G., \& Beard, D. W. (1984). Dimensions of organizational task environments. Administrative Science Quarterly, 52-73. 
Detert, J. R., Treviño, L. K., \& Sweitzer, V. L. (2008). Moral disengagement in ethical decision making: A study of antecedents and outcomes. Journal of Applied Psychology, 93(2), 374.

DeTienne, D. R., Shepherd, D. A., \& De Castro, J. O. (2008). The fallacy of “only the strong survive": The effects of extrinsic motivation on the persistence decisions for underperforming firms. Journal of Business Venturing, 23(5), 528-546.

Devine, K., \& Clock, P. O. (1995). The effect on sunk costs and opportunity costs on a subject. The Mid-Atlantic Journal of Business, 31(1), 25.

Dijker, A. J. (2001). The influence of perceived suffering and vulnerability on the experience of pity. European Journal of Social Psychology, 31(6), 659-676.

Donahue, E. G., Rip, B., \& Vallerand, R. J. (2009). When winning is everything: On passion, identity, and aggression in sport. Psychology of Sport and Exercise, $10(5), 526-534$.

Donaldson, J. M., \& Watson, R. (1996). Loneliness in elderly people: An important area for nursing research. Journal of Advanced Nursing, 24(5), 952-959.

Douglas, E. J., \& Shepherd, D. A. (2000). Entrepreneurship as a utility maximizing response. Journal of Business Venturing, 15(3), 231-251.

Douglas, E. J., \& Shepherd, D. A. (2002). Self-employment as a career choice: Attitudes, entrepreneurial intentions, and utility maximization. Entrepreneurship Theory and Practice, 26(3), 81-90.

Efrat, R. (2005). Bankruptcy stigma: Plausible causes for shifting norms. Emory Bankruptcy Developments Journal, 22, 481-519.

Egri, C. P., \& Herman, S. (2000). Leadership in the North American environmental sector: Values, leadership styles, and contexts of environmental leaders and their organizations. Academy of Management Journal, 43(4), 571-604.

Eisenberg, N. (2000). Emotion, regulation, and moral development. Annual Review of Psychology, 51(1), 665-697.

Fafchamps, M., \& Lund, S. (2003). Risk-sharing networks in rural Philippines. Journal of Development Economics, 71(2), 261-287.

Feather, N. T. (1982). Human values and the prediction of action: An expectancyvalence analysis. In N. T. Feather (Ed.), Expectations and actions: Expectancyvalue models in psychology (pp. 263-292). Hillsdale: LEA.

Feather, N. T. (1990). Bridging the gap between values and actions: Recent applications of the expectancy-value model. In E. T. Higgins \& R. M. Sorrentino (Eds.), Handbook of motivation and cognition: Foundations of social behavior (Vol. 2, pp. 151-192). New York: Guilford Press.

Feather, N. T. (1995). Values, valences, and choice: The influences of values on the perceived attractiveness and choice of alternatives. Journal of Personality and Social Psychology, 68(6), 1135.

Festinger, L. (1957). A theory of cognitive dissonance. Stanford: Stanford University Press.

Fiet, J. O. (2007). A prescriptive analysis of search and discovery. Journal of Management Studies, 44(4), 592-611. 
Fineman, S. (1999). Emotion and organizing. In S. R. Clegg \& C. Hardy (Eds.), Studying organization: Theory and method (pp. 289-310). London: Sage.

Fishbein, M., \& Ajzen, I. (1972). Attitudes and opinions. Annual Review of Psychology, 23(1), 487-544.

Folkman, S., \& Moskowitz, J. T. (2004). Coping: Pitfalls and promise. Annual Review of Psychology, 55, 745-774.

Forbes, D. P., Borchert, P. S., Zellmer-Bruhn, M. E., \& Sapienza, H. J. (2006). Entrepreneurial team formation: An exploration of new member addition. Entrepreneurship Theory and Practice, 30, 225-248.

Gagné, M., \& Deci, E. L. (2005). Self-determination theory and work motivation. Journal of Organizational Behavior, 26(4), 331-362.

Gatewood, E. J., Shaver, K. G., Powers, J. B., \& Gartner, W. B. (2002). Entrepreneurial expectancy, task effort, and performance. Entrepreneurship Theory and Practice, 27(2), 187-206.

Gilad, B., \& Levine, P. (1986). A behavioral model of entrepreneurial supply. Journal of Small Business Management, 24, 45.

Gilinsky, A. S. (1949). Relative self-estimate and the level of aspiration. Journal of Experimental Psychology, 39(2), 256.

Gimeno, J., Folta, T. B., Cooper, A. C., \& Woo, C. Y. (1997). Survival of the fittest? Entrepreneurial human capital and the persistence of underperforming firms. Administrative Science Quarterly, 42, 750-783.

Gist, M. E. (1987). Self-efficacy: Implications for organizational behavior and human resource management. Academy of Management Review, 12(3), 472-485.

Graebner, M. E., \& Eisenhardt, K. M. (2004). The seller's side of the story: Acquisition as courtship and governance as syndicate in entrepreneurial firms. Administrative Science Quarterly, 49(3), 366-403.

Grant, A. M. (2007). Relational job design and the motivation to make a prosocial difference. Academy of Management Review, 32(2), 393-417.

Grant, A. M., \& Berry, J. W. (2011). The necessity of others is the mother of invention: Intrinsic and prosocial motivations, perspective taking, and creativity. Academy of Management Journal, 54(1), 73-96.

Grégoire, D. A., Barr, P. S., \& Shepherd, D. A. (2010). Cognitive processes of opportunity recognition: The role of structural alignment. Organization Science, $21(2), 413-431$.

Gumpert, D. E., \& Boyd, D. P. (1984). The loneliness of the small-business owner. Harvard Business Review, 62(6), 18.

Hagner, D., \& Davies, T. (2002). "Doing my own thing": Supported selfemployment for individuals with cognitive disabilities. Journal of Vocational Rehabilitation, 17(2), 65-74.

Hannafey, F. T. (2003). Entrepreneurship and ethics: A literature review. Journal of Business Ethics, 46(2), 99-110. 
Hauswald, H. (2013). Family businesses' ability to attract new talent: Who is attracted and under what conditions? In Stakeholder trust in family businesses, Familienunternehmen und KMU. Wiesbaden: Springer Gabler.

Hawkley, L. C., \& Cacioppo, J. T. (2010). Loneliness matters: A theoretical and empirical review of consequences and mechanisms. Annals of Behavioral Medicine, 40(2), 218-227.

Haynie, J. M., \& Shepherd, D. (2011). Toward a theory of discontinuous career transition: Investigating career transitions necessitated by traumatic life events. Journal of Applied Psychology, 96(3), 501.

Hemingway, C. A. (2005). Personal values as a catalyst for corporate social entrepreneurship. Journal of Business Ethics, 60(3), 233-249.

Hoang, H., \& Gimeno, J. (2010). Becoming a founder: How founder role identity affects entrepreneurial transitions and persistence in founding. Journal of Business Venturing, 25(1), 41-53.

Hodges, L., \& Carron, A. V. (1992). Collective efficacy and group performance. International Journal of Sport Psychology, 23(1), 48-59.

Hodgins, H. S., \& Knee, C. R. (2002). The integrating self and conscious experience. In E. L. Deci \& R. M. Ryan (Eds.), Handbook of selfdetermination research (pp. 87-100). Rochester: University of Rochester Press.

Hoffman, M. L. (1982). Development of prosocial motivation: Empathy and guilt. In The development of prosocial behavior (pp. 281-313). New York: Academic.

Holland, D. V., \& Shepherd, D. A. (2013). Deciding to persist: Adversity, values, and entrepreneurs' decision policies. Entrepreneurship Theory and Practice, $37(2), 331-358$.

Holt-Lunstad, J., Smith, T. B., \& Layton, J. B. (2010). Social relationships and mortality risk: A meta-analytic review. PLoS Medicine, 7(7), el 000316.

Houlfort, N., Fernet, C., Vallerand, R. J., Laframboise, A., Guay, F., \& Koestner, R. (2015). The role of passion for work and need satisfaction in psychological adjustment to retirement. Journal of Vocational Behavior, 88, 84-94.

Jackofsky, E. F., \& Peters, L. H. (1983). Job turnover versus company turnover: Reassessment of the March and Simon participation hypothesis. Journal of Applied Psychology, 68(3), 490.

Janoff-Bulman, R. (1985). The aftermath of victimization: Rebuilding shattered assumptions. Trauma and its Wake, 1, 15-35.

Jenkins, A. S., Wiklund, J., \& Brundin, E. (2014). Individual responses to firm failure: Appraisals, grief, and the influence of prior failure experience. Journal of Business Venturing, 29(1), 17-33.

Jensen, M. C., \& Meckling, W. H. (1976). Theory of the firm: Managerial behavior, agency costs and ownership structure. Journal of Financial Economics, 3(4), 305-360.

Johnson, P. E., Jamal, K., \& Berryman, R. G. (1991). Effects of framing on auditor decisions. Organizational Behavior and Human Decision Processes, 50(1), 75-105. 
Johnston, M. W., Parasuraman, A., Futrell, C. M., \& Black, W. C. (1990). A longitudinal assessment of the impact of selected organizational influences on salespeople's organizational commitment during early employment. Journal of Marketing Research, 333-344.

Jordan, P. J., Ashkanasy, N. M., \& Hartel, C. E. (2002). Emotional intelligence as a moderator of emotional and behavioral reactions to job insecurity. Academy of Management Review, 27(3), 361-372.

Judge, T. A., \& Bretz, R. D. (1992). Effects of work values on job choice decisions. Journal of Applied Psychology, 77(3), 261.

Kanfer, R. (1990). Motivation theory and industrial and organizational psychology. In M. D. Dunnette (Ed.), Handbook of industrial and organizational psychology (Vol. 1, 2nd ed., pp. 75-130). Palo Alto: Consulting Psychologists Press.

Karpoff, J. M., \& Lott, J. R., Jr. (1993). The reputational penalty firms bear from committing criminal fraud. The Journal of Law and Economics, 36(2), 757-802.

Karpoff, J. M., Lee, D. S., \& Martin, G. S. (2008). The consequences to managers for financial misrepresentation. Journal of Financial Economics, 88(2), 193-215.

Karstedt, S. (2006). Democracy, values, and violence: Paradoxes, tensions, and comparative advantages of liberal inclusion. The Annals of the American Academy of Political and Social Science, 605(1), 50-81.

Katz, J. A. (1994). Modelling entrepreneurial career progressions: Concepts and considerations. Entrepreneurship: Theory and Practice, 19(2), 23-40.

Keil, M. (1995). Escalation of commitment in information systems development: A comparison of three theories. Academy of Management Journal, 8, 348-353.

Keil, M., Mann, J., \& Rai, A. (2000a). Why software projects escalate: An empirical analysis and test of four theoretical models. Management Information Systems Quarterly, 24, 631-664.

Keil, M., Tan, B. C., Wei, K. K., Saarinen, T., Tuunainen, V., \& Wassenaar, A. (2000b). A cross-cultural study on escalation of commitment behavior in software projects. Management Information Systems Quarterly, 24, 299-325.

Kendall, E., Buys, N., Charker, J., \& MacMillan, S. (2006). Self-employment: An under-utilised vocational rehabilitation strategy. Journal of Vocational Rebabilitation, 25(3), 197-205.

Khandwalla, P. N. (1976). The design of effective top management style. Vikalpa, l(2), 4l-58.

Khandwalla, P. N. (1977). The design of organizations. New York: Houghton Mifflin Harcourt P, 29(7), 770-791.

Kirzner, I. M. (1979). Perception, opportunity, and profit. Chicago: University of Chicago Press, 2(3), 1-16.

Knight, F. H. (1921). Risk, uncertainty and profit. Washington, DC: Beard Books, 31(1), 132-152. kopernik.info/en-us/story/howard-weinstein-solar-ear

Kotha, R., \& George, G. (2012). Friends, family, or fools: Entrepreneur experience and its implications for equity distribution and resource mobilization. Journal of Business Venturing, 27(5), 525-543. 
Kunda, Z. (1990). The case for motivated reasoning. Psychological Bulletin, 108, 480.

Kuratko, D. F., Hornsby, J. S., \& Naffziger, D. W. (1997). An examination of owner's goals in sustaining entrepreneurship. Journal of Small Business Management, $35(1), 24$.

Laguna, M. (2013). Self-efficacy, self-esteem, and entrepreneurship among the unemployed. Journal of Applied Social Psychology, 43(2), 253-262.

Langan-Fox, J., \& Roth, S. (1995). Achievement motivation and female entrepreneurs. Journal of Occupational and Organizational Psychology, 68(3), 209-218.

Lant, T. K., Milliken, F. J., \& Batra, B. (1992). The role of managerial learning and interpretation in strategic persistence and reorientation: An empirical exploration. Strategic Management Journal, 13(8), 585-608.

Lee, S. H., Peng, M. W., \& Barney, J. B. (2007). Bankruptcy law and entrepreneurship development: A real options perspective. Academy of Management Review, 32(1), 257-272.

Lee, S. H., Yamakawa, Y., Peng, M. W., \& Barney, J. B. (2011). How do bankruptcy laws affect entrepreneurship development around the world? Journal of Business Venturing, 26(5), 505-520.

Lentz, R., \& Tranaes, T. (2005). Job search and savings: Wealth effects and duration dependence. Journal of Labor Economics, 23(3), 467-489.

Levenson, H. (1981). Differentiating among internality, powerful others, and chance, $1-15$.

Levinthal, D. A., \& March, J. G. (1993). The myopia of learning. Strategic Management Journal, 14(S2), 95-112.

Levitt, B., \& March, J. G. (1988). Organizational learning. Annual Review of Sociology, 14(1), 319-338.

Little, B. L., \& Madigan, R. M. (1997). The relationship between collective efficacy and performance in manufacturing work teams. Small Group Research, $28(4), 517-534$.

Logan, G. D. (1990). Repetition priming and automaticity: Common underlying mechanisms? Cognitive Psychology, 22(1), 1-35.

Lyons, S. T., Duxbury, L., \& Higgins, C. (2007). An empirical assessment of generational differences in basic human values. Psychological Reports, 101(2), 339-352.

Maheswaran, D., \& Sternthal, B. (1990). The effects of knowledge, motivation, and type of message on ad processing and product judgments. Journal of Consumer Research, 17(1), 66-73.

March, J. G., \& Simon, H. A. (1958). Organizations, 57(9), 705-717.

Markman, G. D., Balkin, D. B., \& Baron, R. A. (2002). Inventors and new venture formation: The effects of general self-efficacy and regretful thinking. Entrepreneurship Theory and Practice, 27(2), 149-165.

Martin, R., \& Hewstone, M. (2003). Majority versus minority influence: When, not whether, source status instigates heuristic or systematic processing. European Journal of Social Psychology, 33(3), 313-330. 
Mason, C. M., \& Harrison, R. T. (2002). Is it worth it? The rates of return from informal venture capital investments. Journal of Business Venturing, 17(3), 211-236.

McDermott, R., O’Dea, K., Rowley, K., Knight, S., \& Burgess, P. (1998). Beneficial impact of the homelands movement on health outcomes in central Australian aborigines. Australian and New Zealand Journal of Public Health, 22(6), 653-658.

McGrath, R. G. (1999). Falling forward: Real options reasoning and entrepreneurial failure. Academy of Management Review, 24(1), 13-30.

McMullen, J. S., \& Shepherd, D. A. (2006). Encouraging consensus-challenging research in universities. Journal of Management Studies, 43(8), 1643-1669.

McMullen, J. S., Shepherd, D. A., \& Patzelt, H. (2009). Managerial (in) attention to competitive threats. Journal of Management Studies, 46(2), 157-181.

Mikulincer, M., Gillath, O., Sapir-Lavid, Y., Yaakobi, E., Arias, K., Tal-Aloni, L., \& Bor, G. (2003). Attachment theory and concern for others' welfare: Evidence that activation of the sense of secure base promotes endorsement of selftranscendence values. Basic and Applied Social Psychology, 25(4), 299-312.

Miller, D., \& Friesen, P. H. (1983). Strategy-making and environment: The third link. Strategic Management Journal, 4(3), 22l-235.

Miller, T. L., Grimes, M. G., McMullen, J. S., \& Vogus, T. J. (2012). Venturing for others with heart and head: How compassion encourages social entrepreneurship. Academy of Management Review, 37(4), 616-640.

Mitchell, R. K., Agle, B. R., \& Wood, D. J. (1997). Toward a theory of stakeholder identification and salience: Defining the principle of who and what really counts. Academy of Management Review, 22(4), 853-886.

Mitchell, R. K., Busenitz, L., Lant, T., McDougall, P. P., Morse, E. A., \& Smith, J. B. (2004). The distinctive and inclusive domain of entrepreneurial cognition research. Entrepreneurship Theory and Practice, 28(6), 505-518.

Molloy, G. J., McGee, H. M., O'neill, D., \& Conroy, R. M. (2010). Loneliness and emergency and planned hospitalizations in a community sample of older adults. Journal of the American Geriatrics Society, 58(8), 1538-1541.

Morris, M. W., Williams, K. Y., Leung, K., Larrick, R., Mendoza, M. T., Bhatnagar, D., et al. (1998). Conflict management style: Accounting for cross-national differences. Journal of International Business Studies, 29(4), 729-747.

Muehlebach, A. (2001). "Making place" at the United Nations: Indigenous cultural politics at the UN working group on indigenous populations. Cultural Anthropology, 16(3), 415-448.

Multon, K. D., Brown, S. D., \& Lent, R. W. (1991). Relation of self-efficacy beliefs to academic outcomes. A meta-analytic investigation, 38(1), 30-38.

Nickerson, R. S. (1998). Confirmation bias: A ubiquitous phenomenon in many guises. Review of General Psychology, 2, 175. 
Paldam, M. (2002). The cross-country pattern of corruption: Economics, culture and the seesaw dynamics. European Journal of Political Economy, 18(2), 215-240.

Paolillo, J. G., \& Brown, W. B. (1978). How organizational factors affect R\&D innovation. Research Management, 21(2), 12-15.

Parker, S. C., \& Van Praag, M. (2010). Group status and entrepreneurship. Journal of Economics and Management Strategy, 19(4), 919-945.

Parris, T. M., \& Kates, R. W. (2003). Characterizing and measuring sustainable development. Annual Review of Environment and Resources, 28, 559-586.

Poterba, J. M., Venti, S. F., \& Wise, D. A. (2010). The Asset Cost of Poor Health (No. w16389). Cambridge, MA: National Bureau of Economic Research.

Prahalad, C.K. (2007). Bottom of the pyramid. Presentation at the Strategic Entrepreneurship Journal Launch Conference, 1(1), 1.

Rauch, A., \& Frese, M. (2007). Let's put the person back into entrepreneurship research: A meta-analysis on the relationship between business owners' personality traits, business creation, and success. European Journal of Work and Organizational Psychology, 16(4), 353-385.

Rip, B., Fortin, S., \& Vallerand, R. J. (2006). The relationship between passion and injury in dance students. Journal of Dance Medicine \& Science, 10(1-1), 14-20.

Rohan, M. J. (2000). A rose by any name? The values construct. Personality and Social Psychology Review, 4(3), 255-277.

Rokeach, M. (1973). The nature of human values. New York: Free press.

Rook, K. S. (1984). The negative side of social interaction: Impact on psychological well-being. Journal of Personality and Social Psychology, 46(5), 1097.

Rosenbaum, D. I., \& Lamort, F. (1992). Entry, barriers, exit, and sunk costs: An analysis. Applied Economics, 24(3), 297-304.

Ryan, R. M., \& Deci, E. L. (2000). Self-determination theory and the facilitation of intrinsic motivation, social development, and well-being. American Psychologist, 55(1), 68.

Ryan, R. M., \& Deci, E. L. (2001). On happiness and human potentials: A review of research on hedonic and eudaimonic well-being. Annual Review of Psychology, 52(1), 141-166.

Sabini, J., Garvey, B., \& Hall, A. L. (2001). Shame and embarrassment revisited. Personality and Social Psychology Bulletin, 27(1), 104-117.

Sala, E. (2006). Top predators provide insurance against climate change. Trends in Ecology \& Evolution, 21(9), 479-480.

Sarasvathy, S. D. (2001). Causation and effectuation: Toward a theoretical shift from economic inevitability to entrepreneurial contingency. Academy of Management Review, 26(2), 243-263.

Scheinberg, S., \& MacMillan, I. (1988). An eleven-country study of the motivation to start a business. Wellesley: Frontiers of Entrepreneurship Research, Babson College. 
Schjoedt, L., \& Shaver, K. G. (2007). Deciding on an entrepreneurial career: A test of the pull and push hypotheses using the panel study of entrepreneurial dynamics data. Entrepreneurship Theory and Practice, 31(5), 733-752.

Schumpeter, J. A. (1961). The theory of economic development: An inquiry into profits, capital, credit, interest, and the business cycle (trans: R. Opie, p. 244). Cambridge, MA: Harvard University Press.

Schwartz, S. H. (1992). Universals in the content and structure of values: Theoretical advances and empirical tests in 20 countries. Advances in Experimental Social Psychology, 25, 1-65.

Schwartz, S. H., \& Bilsky, W. (1990). Toward a theory of the universal content and structure of values: Extensions and cross-cultural replications. Journal of Personality and Social Psychology, 58(5), 878-891.

Selden, P. D., \& Fletcher, D. E. (2015). The entrepreneurial journey as an emergent hierarchical system of artifact-creating processes. Journal of Business Venturing, 30(4), 603-615.

Semadeni, M., Cannella, A. A., Jr., Fraser, D. R., \& Lee, D. S. (2008). Fight or flight: Managing stigma in executive careers. Strategic Management Journal, $29(5), 557-567$.

Shah, J. Y., Friedman, R., \& Kruglanski, A. W. (2002). Forgetting all else: On the antecedents and consequences of goal shielding. Journal of Personality and Social Psychology, 83(6), 1261-1281.

Shane, S., Kolvereid, L., \& Westhead, P. (1991). An exploratory examination of the reasons leading to new firm formation across country and gender. Journal of Business Venturing, 6(6), 431-446.

Shane, S., Locke, E. A., \& Collins, C. J. (2003). Entrepreneurial motivation. Human Resource Management Review, 13(2), 257-279.

Shapiro, A., \& Sokol, L. (1982). The social dimensions of entrepreneurship. In A. C. Kent, L. D. Sextopn, \& H. K. Vesper (Eds.), Encyclopedia of entrepreneurship (pp. 72-90).

Shaver, K. G., \& Scott, L. R. (2002). Person, process, choice. Entrepreneurship: Critical Perspectives on Business and Management, 2(2), 334.

Shaver, K. G., Gartner, W. B., Crosby, E., Bakalarova, K., \& Gatewood, E. J. (2001). Attributions about entrepreneurship: A framework and process for analyzing reasons for starting a business. Entrepreneurship: Theory and Practice, 26(2), 5-33.

Shepherd, D. A. (2003). Learning from business failure: Propositions of grief recovery for the self-employed. Academy of Management Review, 28(2), 318-328.

Shepherd, D. A., \& Cardon, M. S. (2009). Negative emotional reactions to project failure and the self-compassion to learn from the experience. Journal of Management Studies, 46(6), 923-949.

Shepherd, D. A., \& DeTienne, D. R. (2005). Prior knowledge, potential financial reward, and opportunity identification. Entrepreneurship Theory and Practice, 29(1), 91-112. 
Shepherd, D. A., \& Patzelt, H. (2015). Harsh evaluations of entrepreneurs who fail: The role of sexual orientation, use of environmentally friendly technologies, and observers' perspective taking. Journal of Management Studies, 52(2), 253-284.

Shepherd, D. A., Patzelt, H., \& Wolfe, M. (2011). Moving forward from project failure: Negative emotions, affective commitment, and learning from the experience. Academy of Management Journal, 54(6), 1229-1259.

Shepherd, D. A., Patzelt, H., \& Baron, R. A. (2013). "I care about nature, but...": Disengaging values in assessing opportunities that cause harm. Academy of Management Journal, 56(5), 1251-1273.

Shepherd, D. A., Thorgren, S., \& Wincent, J. (2018). Fear of failure promoting opportunity pursuit: Potential payoffs, fear of failure, and obsessive passion (Working paper). Lulea, Sweden.

Shook, C. L., Priem, R. L., \& McGee, J. E. (2003). Venture creation and the enterprising individual: A review and synthesis. Journal of Management, 29(3), 379-399.

Smilor, R. W. (1997). Entrepreneurship: Reflections on a subversive activity. Journal of Business Venturing, 12(5), 341-346.

Smith, R., \& McElwee, G. (2011). After the fall: Developing a conceptual scriptbased model of shame in narratives of entrepreneurs in crisis! International Journal of Sociology and Social Policy, 31(1/2), 91-109.

Spash, C. L. (2002). Greenhouse economics: Values and ethics. London: Taylor and Francis.

Spicer, P. (2001). Culture and the restoration of self among former American Indian drinkers. Social Science \& Medicine, 53(2), 227-240.

Srinivasan, T. U., Carey, S. P., Hallstein, E., Higgins, P. A. T., Kerr, A. C., Koteen, L. E., et al. (2008). The debt of nations and the distribution of ecological impacts from human activities. Proceedings of the National Academy of Sciences of the United States of America, 105, 1768-1773.

Srivastava, A., Locke, E. A., Judge, T. A., \& Adams, J. W. (2010). Core selfevaluations as causes of satisfaction: The mediating role of seeking task complexity. Journal of Vocational Behavior, 77(2), 255-265.

Stanton, A. L., Danoff-burg, S., \& Huggins, M. E. (2002). The first year after breast cancer diagnosis: Hope and coping strategies as predictors of adjustment. Psycho-Oncology, 11(2), 93-102.

Staw, B. M. (1981). The escalation of commitment to a course of action. Academy of Management Review, 6(4), 577-587.

Staw, B. M., \& Fox, F. V. (1977). Escalation: The determinants of commitment to a chosen course of action. Human Relations, 30(5), 431-450.

Staw, B. M., \& Ross, J. (1980). Commitment in an experimenting society: A study of the attribution of leadership from administrative scenarios. Journal of Applied Psychology, 65(3), 249. 
Staw, B. M., McKechnie, P. I., \& Puffer, S. M. (1983). The justification of organizational performance. Administrative Science Quarterly, 28, 582-600.

Stephan, Y., Deroche, T., Brewer, B. W., Caudroit, J., \& Le Scanff, C. (2009). Predictors of perceived susceptibility to sport-related injury among competitive runners: The role of previous experience, neuroticism, and passion for running. Applied Psychology, 58(4), 672-687.

Stevenson, H. H. (1983). A perspective on entrepreneurship. Boston: Harvard Business School, 30(1), 1-22.

Stewart, W. F., Ricci, J. A., Chee, E., Morganstein, D., \& Lipton, R. (2003). Lost productive time and cost due to common pain conditions in the US workforce. JAMA, 290(18), 2443-2454.

Sugisawa, H., Liang, J., \& Liu, X. (1994). Social networks, social support, and mortality among older people in Japan. Journal of Gerontology, 49(1), S3-S13.

Sutton, R. I., \& Callahan, A. L. (1987). The stigma of bankruptcy: Spoiled organizational image and its management. Academy of Management Journal, 30(3), $405-436$.

Thøgersen, J., \& Ölander, F. (2002). Human values and the emergence of a sustainable consumption pattern: A panel study. Journal of Economic Psychology, 23(5), 605-630.

Thurston, R. C., \& Kubzansky, L. D. (2009). Women, loneliness, and incident coronary heart disease. Psychosomatic Medicine, $71(8), 836$.

Tourtellot, J. B. (2007). 111 islands. National Geographic Traveler, 24(8), 108-127.

Tsai, W. M. H., MacMillan, I. C., \& Low, M. B. (1991). Effects of strategy and environment on corporate venture success in industrial markets. Journal of Business Venturing, 6(1), 9-28.

Tushman, M. L. (1977). Special boundary roles in the innovation process. Administrative Science Quarterly, 22, 587-605.

Tushman, M. L., \& Anderson, P. (1986). Technological discontinuities and organizational environments. Administrative Science Quarterly, 31, 439-465.

Ucbasaran, D., Lockett, A., Wright, M., \& Westhead, P. (2003). Entrepreneurial founder teams: Factors associated with member entry and exit. Entrepreneurship Theory and Practice, 28(2), 107-128.

Ucbasaran, D., Shepherd, D. A., Lockett, A., \& Lyon, S. J. (2013). Life after business failure: The process and consequences of business failure for entrepreneurs. Journal of Management, 39(1), 163-202.

United Nations millennium declaration. (2000). United Nations General Assembly, 35(4), 347-359.

U.S. Census Bureau. (2002). Census 2000 summary file. Retrieved http://factfinder. census.gov

Utsch, A., Rauch, A., Rothfufs, R., \& Frese, M. (1999). Who becomes a small scale entrepreneur in a post-socialist environment: On the differences between entre- 
preneurs and managers in East Germany. Journal of Small Business Management, $37(3), 31$.

Vallerand, R. J., \& Houlfort, N. (2003). Passion at work. Emerging Perspectives on Values in Organizations, 175-204.

Vallerand, R. J., Blanchard, C., Mageau, G. A., Koestner, R., Ratelle, C., Léonard, M., et al. (2003). Les passions de l'ame: on obsessive and harmonious passion. Journal of Personality and Social Psychology, 85(4), 756.

Vallerand, R. J., Ntoumanis, N., Philippe, F. L., Lavigne, G. L., Carbonneau, N., Bonneville, A., et al. (2008). On passion and sports fans: A look at football. Journal of Sports Sciences, 26(12), 1279-1293.

Vallerand, R. J., Paquet, Y., Philippe, F. L., \& Charest, J. (2010). On the role of passion for work in burnout: A process model. Journal of Personality, 78(1), 289-312.

Vandekerckhove, W., \& Dentchev, N. A. (2005). A network perspective on stakeholder management: Facilitating entrepreneurs in the discovery of opportunities. Journal of Business Ethics, 60(3), 221-232.

Vroom, V. H. (1964). Work and motivation. New York: Willey.

Wanberg, C. R., Kanfer, R., \& Rotundo, M. (1999). Unemployed individuals: Motives, job-search competencies, and job-search constraints as predictors of job seeking and reemployment. Journal of Applied Psychology, 84(6), 897.

Wasserman, N. (2008). The founder's dilemma. Harvard Business Review, 86, 102-109.

Wasserman, N., Nohria, N., \& Anand, B. N. (2001). When does leadership matter? The contingent opportunities view of CEO leadership, 2-4.

Weiss, K. B., Sullivan, S. D., \& Lyttle, C. S. (2000). Trends in the cost of illness for asthma in the United States, 1985-1994. Journal of Allergy and Clinical Immunology, 106(3), 493-499.

White, J., Bandura, A., \& Bero, L. A. (2009). Moral disengagement in the corporate world. Accountability in Research, 16(1), 41-74.

Wiesenfeld, B. M., Wurthmann, K. A., \& Hambrick, D. C. (2008). The stigmatization and devaluation of elites associated with corporate failures: A process model. Academy of Management Review, 33(1), 231-251.

Wiklund, J., Patzelt, H., \& Dimov, D. (2016). Entrepreneurship and psychological disorders: How ADHD can be productively harnessed. Journal of Business Venturing Insights, 6, 14-20.

Wood, J. V., Saltzberg, J. A., Neale, J. M., Stone, A. A., \& Rachmiel, T. B. (1990). Self-focused attention, coping responses, and distressed mood in everyday life. Journal of Personality and Social Psychology, 58(6), 1027.

Woodman, R. W., Sawyer, J. E., \& Griffin, R. W. (1993). Toward a theory of organizational creativity. Academy of Management Review, 18(2), 293-321. 
Zahra, S. A., \& Covin, J. G. (1995). Contextual influences on the corporate entrepreneurship-performance relationship: A longitudinal analysis. Journal of Business Venturing, 10(1), 43-58.

Zhao, H., \& Seibert, S. E. (2006). The big five personality dimensions and entrepreneurial status: a meta-analytical review. Journal of Applied Psychology, 91, (2), 259-271.

Zhao, H., Seibert, S. E., \& Hills, G. E. (2005). The mediating role of self-efficacy in the development of entrepreneurial intentions. Journal of Applied Psychology, 90(6), 1265.

Zhao, H., Seibert, S. E., \& Lumpkin, G. T. (2010). The relationship of personality to entrepreneurial intentions and performance: A meta-analytic review. Journal of Management, 36(2), 381-404.

Open Access This chapter is licensed under the terms of the Creative Commons Attribution 4.0 International License (http://creativecommons.org/licenses/ by $/ 4.0 /)$, which permits use, sharing, adaptation, distribution and reproduction in any medium or format, as long as you give appropriate credit to the original author(s) and the source, provide a link to the Creative Commons license and indicate if changes were made.

The images or other third party material in this chapter are included in the chapter's Creative Commons license, unless indicated otherwise in a credit line to the material. If material is not included in the chapter's Creative Commons license and your intended use is not permitted by statutory regulation or exceeds the permitted use, you will need to obtain permission directly from the copyright holder.

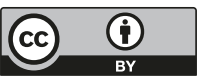

